\title{
What Drives Security Issuance Decisions Of Firms Listed On The Johannesburg Stock Exchange: Market Timing Or Dynamic Trade-Off Theory Or Both?
}

Vusani Moyo, University of Venda, South Africa

\begin{abstract}
This study used panel datasets from 143 Johannesburg Stock Exchange-listed non-financial firms and four variants of the partial adjustment model fitted with the random effects Tobit estimator to investigate the validity of the market timing, trade-off and pecking order hypotheses of capital structure. The study documents that leverage is positively correlated to the modified external finance weighted average market-to-book ratio (EFWAMB). Firm profitability and growth rate are negatively correlated to leverage whilst firm size and asset tangibility are positively correlated to leverage. The firms also have target leverage ratios towards which they actively adjust at an unbiased speed of $41.80 \%$ for the market-to-debt ratio and $52.82 \%$ for the book-to-debt ratio. EFWAMB has a negligible effect on the firms' speeds of adjustment towards target leverage. The results are robust. These results reject the market timing hypothesis in support of the dynamic trade-off and pecking order hypotheses. They further confirm the fact that these two theories of capital structure are not mutually-exclusive.
\end{abstract}

Keywords: Capital Structure; Market Timing Theory; Trade-Off Theory; Pecking Order Theory; Speed of Adjustment; Random Effects Tobit

\section{INTRODUCTION}

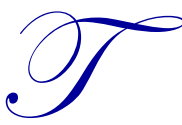

he market timing theory of Baker and Wurgler (2002) which was developed from the initial empirical works of Korajczyk, Lucas and McDonald (1992) and of Lucas and McDonald (1990) has emerged as a leading alternative to the trade-off and pecking order theories in explaining corporate financing behaviour. The theory states that the observed capital structures are a reflection of past attempts by managers to time both the equity and the debt markets in raising capital. According to the market timing theory, the security choice issuance and repurchase decisions are affected by the current state of the capital markets, which ultimately reflect the current valuation of the equities and debts securities, as well as the current interest rates (Marsh, 1982). Thus, if managers follow the market timing hypothesis, they will only issue shares when they believe that the firm's shares are currently overvalued, and will only repurchase shares when they believe that the shares are undervalued (Barclay \& Smith, 2005).

A study by Peyer and Vermaelen (2009) found that, firms issue equity when the stock market is high, as this signals that management believes the shares are overvalued. Conversely, the repurchase of shares is attractive when the market is low, as the shares will be undervalued. Dittmar (2000) found that firms repurchase shares to exploit potential undervaluation. Welch (2004) contends that stock market performance is the most important determinant of corporate financing. The main advantage of issuing equity when the market is high is that the firm maximises its net cash issuance proceeds during such times. The chances of issuance successes are also very high during such periods. A rising stock market will mechanically reduce the leverage ratio measured in market value terms. Thus, when the stock market is high, firms are more inclined to issue equity than debt (Hovakimian, Opler \& 
Titman, 2001). The implication of this financing behaviour is that a rising stock market is associated with low leverage.

The decision to issue debt also depends on the state of the bond market and the prevailing interest rates. The cost of debt is therefore a major determinant of the debt issuance decision. This implies that firms will time debt markets; they will issue debt when interest rates are low. The empirical findings of Barry, Mann, Mihov and Rodriguez (2008) and of Henderson, Jagadeesh and Weisbach (2006) confirm the market timing behaviour with regard to debt issuance. Firms issue less debt when interest rates are high, because high interest rates reduce the value of the loan in real terms, as firms pay a higher price for a small loan amount. The market timing theory does not, however, explain what happens when the stock market is low and the bond market is high. Would the firm be indifferent about issuing equity or debt, or would it do dual issuances under these circumstances?

In summary, the market timing theory rejects the idea of an optimal or target capital structure capital structure as hypothesised by the dynamic trade-off theory. It also rejects the financing hierarchy hypothesis of the pecking order theory. According to the market timing theory, the sole determinant of the corporate financing decision is the over/undervaluation of securities. This implies that firms do not rebalance their capital structures, and hence the target speed of adjustment (SOA) is zero. Furthermore, it implies that the interest tax shields, non-debt tax shields, agency costs and the financing hierarchy play no role in the corporate financing decision.

The main objective of this study was to test for the validity of these assertions in the context of firms from an emerging economy. The question that was asked is: Do firms from emerging economies in Africa time the market in their security issuance decisions?

As is the practice with other leading capital structure theories, Baker and Wurgler (2002) used data from COMPUSTAT firms in developing the market timing theory. Subsequent tests of the theory have also been limited to US and European firms, with studies by Bruinshoofd and De Haan (2012) and De Bie and De Haan (2007) rejecting the hypotheses of the market timing theory in explaining the financing behaviours of UK, Dutch and continental European firms. Another study by Mahajan and Tartaroglu (2008) using data drawn from firms in all the G-7 countries, documents evidence that is inconsistent with the market timing hypothesis and more in line with the dynamic trade-off theory. The validity of the market timing theory in explaining the financing behaviours of nonfinancial firms listed of the JSE still remains untested. Oztekin and Flannery (2012) and De Jong, Kabir and Nguyen (2008) documented that the capital structure of firms is largely influenced by the country's institutional factors, such as ease of access to capital markets, level of information asymmetry, financial constraints and aggregate adjustment costs. These factors vary across countries and economic regions. Studies by Booth, Aivazian Demirguc-Kunt and Maksimovic (2001), Gwatidzo and Ojah and Singh (1999) found that the South African and other emerging countries' institutional factors, such as, level of development of the capital markets, size and sophistication of the corporate bond markets, country credit ratings, level of development of tax and legal systems, and protection of property rights, differ significantly from those of developed countries such as the USA and the countries in continental Europe. A study by Fan, Wei and Xu (2011) also found persistent structural and behavioural heterogeneity between firms in emerging markets and those in developed economies. These institutional, structural and behavioural differences therefore justify a separate study of South African firms, as findings from studies using data from developed countries may be inapplicable to firms in South Africa and other emerging countries.

Furthermore, the leading tests on the validity of the market timing theory use biased panel data estimators such the ordinary least squares (OLS) regressions (Baker \& Wurgler, 2002; De Bie \& De Haan, 2007; and Mahajan \& Tartaroglu, 2008) and the feasible generalised least squares (FGLS) estimator (Bruinshoofd \& De Haan, 2012). According to Elsas and Florysiak (2013), these estimators are biased, as they do not take into account the fractional nature of the dependable variables. Debt ratios are bounded between 0 and 1. All the above tests also shunned the use of the partial adjustment model which, if used, would allow the testing of the effect of including the market timing measure in the vector of firm-specific variables used to estimate the firm's target SOA. Inclusion of this measure is expected to reduce the SOA to zero. 
The main questions that arise are: Can the market timing theory explain the financing behaviour of nonfinancial firms listed on the JSE? What is the unbiased SOA for JSE-listed non-financial firms? Does the market timing measure have any impact on the firm's SOA?

The current study used panel datasets obtained from a sample of 143 JSE-listed non-financial firms and the partial adjustment regression model fitted with the random effects Tobit estimator to test for the validity of the market timing hypothesis in explaining the observed capital structures. The period covered was from 2003 to 2012.

The main findings of the study are as follows: The modified market timing measure is positively correlated to both the market-to-debt ratio (MDR) and the book-to-debt ratio (BDR). Firm profitability and growth rate are negatively correlated to both the MDR and the BDR. The variables firm size and asset tangibility are negatively correlated to both the MDR and the BDR. The firms investigated exhibit a significant positive SOA. The unbiased SOA for the full sample is $41.80 \%$ (half-life of 1.28 years) for the MDR and $52.82 \%$ (half-life of 0.92 years) for the BDR. The market timing measure has a negligible effect on the firms' SOA towards target leverage. These results reject the market timing hypothesis in support of the dynamic trade-off and pecking order theories. The results strongly support the dynamic trade-off theory and are robust.

The remainder of the paper is structured as follows: Section 2 provides a review of the related literature and provides a basis for hypothesis development. Section 3 contains the data sources and methodology used. Section 4 discusses the results of the study, and Section 5 concludes the study.

\section{LITERATURE REVIEW AND HYPOTHESIS DEVELOPMENT}

The implication of the market timing theory are that persistently overvalued firms are characterised by low leverages whilst persistently undervalued firms are characterised by high leverages. The direct measure of equity valuation is the firm's market-to-book ratio or actual share returns. Equity overvaluation occurs when market values are higher than book values (Mahajan \& Tartaroglu, 2008). Thus, according to the market timing theory, leverage is inversely related to the firm's historical market-to-book ratio. The propensity to issue equity therefore increases with an increase in the firm's market-to-book ratio.

Korajczyk et al. (1992) concede that share mispricing results from a reduction in information asymmetry between agents and investors. This reduction in information asymmetry occurs when agents release information about the future prospects of the firm based on the general positive outlook of the economy. The firm's prospects are likely to be better during boom periods, and firms are therefore likely to issue equity during boom periods. The release of this information increases the firm's market-to-book ratio thereby lowering the firm's external financing costs. According to Baker and Wurgler (2002), the share mispricing anomaly (overvaluation) can also be caused by irrational investors who misprice the firm's shares by ignoring the fundamentals of firm valuation. In both cases, managers exploit share over-pricing by issuing equity, and this sends a signal to investors that the firm's shares are overpriced. Conversely, managers can also exploit the under-pricing of the firm's shares by either issuing debt instead of equity or buying back the firm's shares.

Investors respond by scaling down the share prices (in cases of overpriced shares) or scaling up the share prices (in cases of under-priced shares). According to Smith (1986), the share price of industrial firms can fall by as much as $3.14 \%$ on the announcement of a share issuance while a straight bond issuance announcement decreases the share price by only $0.26 \%$. The rationale for market timing equity issuances is that managers want to maximise their net proceeds from security issuances and they can only achieve this if the shares are either correctly priced or overpriced. Managers have no incentive for issuing under-priced shares. Again, share prices rise after a repurchase, as investors correct this undervaluation (Chan, Ikenberry \& Lee, 2007; and Dittmar, 2000).

If firms follow the market timing theory, it means that low leverage firms raise capital when their valuations are high and hence they issue equity. Some of the equity proceeds may be used to retire debt. According to Lucas and McDonald (1990), equity issuances are preceded by, on average, an abnormal positive share return and an abnormal rise in the market. In contrast, high leverage firms raise capital when their valuations are low and hence issue debt capital. Spiess and Affleck-Graves (1999) found that debt issuances are signals that the firm's shares are 
undervalued. The debt may also be used to finance share repurchases, as the firm can buy back the shares at a discount (the shares are undervalued). According to Baker and Wurgler (2002), the effects of market timing are persistent, lasting more than 10 years.

The high share returns, are however, not the only reason for the increased propensity towards equity issuance. According to Alti and Sulaeman (2012), the likelihood of issuing equity peaks when high share returns coincide with a strong demand from institutional investors. In cases where the institutional investor demand remains low, firms may still issue debt, even if share returns are high. Furthermore, Dittmar and Thakor (2007) propose the managerial investment autonomy theory, which states that managers are likely to issue or retire a security if they are likely to agree with shareholders; this implies an agreement parameter for security issuance. These findings, together with the market timing theory, imply that the security issuance decision is driven by security over/under-valuation and institutional investor demand, as well as the investment autonomy theory.

As with other leading capital structure theories, the evidence concerning the market timing theory is mixed. A survey done by Graham and Harvey (2001) indicated that up to $30 \%$ of the Chief Financial Officers see equity undervaluation as an important factor in making debt-equity issuance decisions. A number of studies including those of Burch, Christie and Nanda (2004), Bougatef and Chichti (2010), Denis (2012) and Elliott, Koeter-Kant and Warr (2008) have documented that equity overvaluation drives equity issuance decisions. The propensity to issue shares coincides with high market-to-book values or high share returns. Equity issuances are preceded by high market-tobook values, high share returns and increases in share prices. According to Jenter (2005), the perception of share mispricing is firmly behind the phenomenon of market timing in IPOs, SEOs, share repurchases and merger and acquisitions financing.

The findings of the study by Hovakimian, Hovakimian and Tehranian (2004) confirm that equity buybacks follow a pattern opposite to that observed in market timing. Firms only purchase shares when they believe that they are undervalued, as this enables the firms to get a discount on the purchase price (Ikenberry, Lakonishok \& Vermaelen, 2000).

The empirical findings of studies by Baxamusa (2011), De Bie and De Haan (2007), Frank and Goyal (2004), Hovakimian (2006), and Walker and Yost (2008), however, reject the market timing theory in favour of the dynamic trade-off theory. These studies, together with that of Kayhan and Titman (2007), found that the effects of market timing are non-persistent. According to Mahajan and Tartaroglu (2008), firms fully rebalance their capital structures within five years after equity issuances, thus fully eliminating the effects of market timing on the capital structure. Alti (2006) found that the market timing effects do not last more than 12 months and that the effects are fully eliminated by the second year.

According to Hovakimian et al (2001), equity issuances and repurchase decisions are designed to move the firm towards its optimal target capital structure; the decision has nothing to do with timing the market. The security issuance and repurchase decisions are meant to eliminate optimal capital structure target deviation spreads that result from cumulative profits and losses. Equity issuances are also likely to simply signal management's confidence about future earnings rather than the timing of the market (Myers \& Majluf, 1984).

In summary, the available evidence on market timing is currently inconclusive.

\section{The Market Timing Measures}

The pioneering study of Baker and Wurgler (2002) identifies the external finance-weighted average market-to-book ratio $\left(E F W A M B_{t}^{B W}\right)$ as a measure of the firm's market timing behaviour. The measure is defined as follows:

$$
E F W A M B_{t}^{B W}=\sum_{s=1}^{t-1} \frac{e_{S}+d_{s}}{\sum_{r=1}^{t-1} e_{r}+d_{r}} \times M B_{S}
$$


Where $e$ and $d$ denote net equity and total debt issuances respectively; $M B$ is the market-to-book ratio, suffixes $S$ and $r$ represent time. Baker and Wurgler (2002) define equity issuances as a change (increase) in the book value of share capital, and they define debt issuances as a change (increase) in the book value of debt. The ratio $\frac{e_{S}+d_{s}}{\sum_{r=1}^{t-1} e_{r}+d_{r}}$ is the ratio of the current period's external finance to the total external finance over the study period, which in this study is the period from 2003 to 2012. The implication of this measure is that firms that time the market tend to have a high $E F W A M B_{t}^{B W}$ since they issue more equity and less long-term debt when the market-to-book ratio $(M B)$ is high.Thus $E F W A M B_{t}^{B W}$ is negatively correlated to leverage. This measure includes both short-term and long-term debt issuances. Bruinshoofd and De Haan (2012) argue that the inclusion of short-term debt is inappropriate, as issuance of short-term debt is not necessarily a consequence of timing the market-it is only longterm debt, rather than total debt, that accurately represents the timing of security issuance decisions. They modify the Baker and Wurgler (2002) measure to only include long-term debt and specify the resulting measure as:

$$
E F W A M B_{t}^{B W}=\sum_{s=1}^{t-1} \frac{e_{s}+l t d_{r}}{\sum_{r=1}^{t-1} e_{r}+l t d_{r}} \times M B_{S}
$$

Where ltd denotes long-term debt issuances.

To allow for a comparison between the levels of the $E F W A M B_{t}$, Bruinshoofd and De Haan (2012) further scale the $E F W A M B_{t}^{B W}$ market timing measure by the average level of the market-to-book ratio over each firm's entire sample period, $\overline{M B}$. The modified market timing measure, $E F W A M B_{t}^{B D}$, becomes:

$$
E F W A M B_{t}^{B D}=\frac{1}{\overline{M B}} \sum_{s=1}^{t-1} \frac{e_{S}+l t d_{s}}{\sum_{r=1}^{t-1} e_{r}+l t d_{r}} \times M B_{S}
$$

The scaling implies that $E F W A M B_{t}^{B D} \geq 1$ if the firm times the market and $E F W A M B_{t}^{B D}<1$ if the market conditions play no role in security-type issuance decisions. Furthermore, in contrast to the original $E F W A M B_{t}^{B W}$ measure, this modified measure of market timing allows for direct interpretation of the regression results. The current study uses this modified measure of market timing behaviour. If South African non-financial firms time the market in their security issuance decisions, then the leverage will be significantly negatively correlated to $E F W A M B_{t}^{B D}$. A positive correlation or an insignificant negative correlation, in contrast, would validate the static trade-off theory.

\section{Market Timing and the Leading Capital Structure Theories}

Myers (1984:576) contends that the trade-off and pecking order theories are the two leading capital structure theories that explain the financing behaviours of firms. These theories are however, not mutually-exclusive (Barclay \& Smith, 2005; Moyo, Wolmarans \& Brümmer (2013) and Mukherjee \& Mahakud, 2012). The trade-off theory which Kraus and Litzenberger (1973) developed from the seminal work of Modigliani and Miller (1963) and other traditional theorists states that firms have an optimal financing mix where firm value is maximised. This optimal mix occurs at a point where the marginal benefits of tax shields are equal to the marginal agency and financial distress costs (Modigliani \& Miller, 1963; and Myers, 2001).

According to Hovakimian, Opler and Titman (2002), the static trade off theory can be replaced by the more relevant dynamic trade-off theory, which contends that, even if firms have target leverage ratios, these are rarely static. As the cost of deviating from the target is very small (less than $0.5 \%$ of firm value), the observed leverage ratios fluctuate around the target within an acceptable range (Ju, Parrino, Poteshman \& Weisbach, 2005). The deviations from the optimal target debt ratio are corrected through the manipulation of financing means (Byoun, 2008; and Kayhan \& Titman, 2007). The rate of covering the target deviation spread defines the firm's SOA towards the target leverage ratio. The adjustment cannot be immediate, as firms face firm-specific adjustment costs in the form of information asymmetries, transaction costs and the opportunity costs of deviating from the target leverage (Elsas \& Florysiak, 2011). This implies a positive SOA towards the target optimal capital structure. The SOA is a function of firm-specific factors, target deviation spread and macro-economic factors (Drobetz \& Wanzernried, 2006; and Hovakimian \& Li, 2011). Table 1 below, adapted from (Moyo et al, 2013) shows the SOA results from selected empirical studies. 
Table 1. Results of Selected Empirical Tests on Target Adjustment Speeds

\begin{tabular}{lccc}
\hline \multicolumn{1}{c}{ Study and method used } & Country of study & Speed of adjustment & Dependent Variable \\
\hline $\begin{array}{l}\text { Antoniou, Guney and Paudyal (2008) } \\
\text { 2-step system GMM procedure }\end{array}$ & $\begin{array}{l}\text { UK, USA, France, } \\
\text { Germany \& Japan }\end{array}$ & $32.00 \%$ & market value of equity \\
\hline $\begin{array}{l}\text { Flannery and Rangan (2006) } \\
\text { Fama and MacBeth (1973) }\end{array}$ & USA & $36.00 \%$ & market value of equity \\
$\begin{array}{l}\text { Elsas and Florysiak (2011) } \\
\text { DPF \& the Blundell and Bond(1998) }\end{array}$ & USA & $\begin{array}{c}26.30 \% \& \\
25.60 \%\end{array}$ & market value of equity \\
\hline $\begin{array}{l}\text { Kayhan and Titman (2007) } \\
\text { Tobit, OLS and bootstrapping }\end{array}$ & USA & $8.00 \%$ & book value of equity \\
\hline $\begin{array}{l}\text { Hovakimian and Li (2011) } \\
\text { OLS and fixed effects methods }\end{array}$ & USA & $5.5-7.40 \%$ & book value of equity \\
\hline $\begin{array}{l}\text { Huang and Ritter (2009) } \\
\text { Long differencing technique }\end{array}$ & USA & $21.00 \%$ & book value of equity \\
\hline $\begin{array}{l}\text { Mukherjee and Mahakud (2012) } \\
\text { system GMM procedure }\end{array}$ & India & $43.00 \%$ & Total long-term debt \\
\hline $\begin{array}{l}\text { Ramjee and Gwatidzo (2012) } \\
\text { system GMM procedure }\end{array}$ & South Africa & $65.00 \%$ & $\begin{array}{c}\text { Market value of equity } \\
\text { Book value of equity }\end{array}$ \\
\hline $\begin{array}{l}\text { Moyo, Wolmarans and Brümmer (2013) } \\
\text { DPF / the Blundell and Bond(1998) }\end{array}$ & South Africa & $\begin{array}{c}42.44 \% / 64.89 \% \\
57.64 \% / 74.44 \%\end{array}$ \\
$\begin{array}{l}\text { Legend: QMLE= quasi-maximum likelihood estimation; OLS = Ordinary least squares; GMM = generalised method of moment and } \\
\text { DPF = the dynamic panel data with a fractional dependent variables estimator (it is equivalent to the random effects Tobit estimator) }\end{array}$
\end{tabular}

According to the dynamic trade-off theory, the security issuance decision is driven by the need to reduce or eliminate the target deviation spread, thus maximising firm value (Hovakimian et al, 2001). Firms generally have a positive SOA. It is also possible to have a negative SOA in the case where the firm over-adjusts its capital structure (Drobetz \& Wanzenried, 2006).

In contrast to the dynamic trade-off theory, the pecking order theory of Myers (1984) and Myers and Majluf (1984) is based on the existence of information asymmetry between managers and investors. The theory rejects the idea of an optimal capital structure as proposed by the dynamic trade-off theory. According to the pecking order theory, security-type issuance decisions are driven by issuance costs and the size of the firm's internal funds deficiency. The internal funds deficiency is a function of the firm's capital expenditure, changes in working capital, dividends paid, current portion of long-term debt and cash flow from operations (Shyam-Sunder \& Myers, 1999). To minimise external financing costs, firms finance their internal funds deficiencies in a pecking order. They issue securities in a pecking order with low risk debt being the first choice, followed by hybrid instruments and, lastly, equity (Tong \& Green, 2005).

Thus according to both the dynamic trade-off and pecking order theories, the pricing of securities (over/undervaluation) plays no role in the security-type issuance decision. The findings of Bruinshoofd and De Haan (2012) confirm that UK and European firms violate the market timing theory, as they raise debt when the stock market is high. This financing behaviour is in line with the pecking order theory. A number of studies, including those of Elsas and Florysiak (2011), Hovakimian and Li (2011), Huang and Ritter (2009), Leary and Roberts (2005), Moyo et al (2013), Mukherjee and Mahakud, (2012), and Ramjee and Gwatidzo (2012), found that firms actively rebalance their capital structures towards the optimal capital structure. This implies that the security issuance decisions are mainly driven by the need eliminate the target capital structure deviation spread. These findings invalidate both the market timing and pecking order theories.

The findings of Dong, Loncarski, Ter Horst and Veld (2012), however, confirm that the market timing and pecking order theories are not mutually exclusive. They indicated that the least financially constrained firms are likely to time their equity issuances and share repurchases. The financing decisions are jointly determined by the need for financial flexibility and the need to exploit the mispricing of shares. 


\section{Firm-Specific Determinants of Leverage}

To control for firm-specific effects, the final regression model used in the current study includes the main firm-specific determinants of leverage; and to test whether the dynamic trade-off, pecking order and market timing theories are mutually exclusive, leverage was regressed on market timing measures ( $E F W A M B_{t}^{B W}$ or $E F W A M B_{t}^{B D}$ ) and a set of firm-specific key determinants of leverage. Rajan and Zingales (1995) and Frank and Goyal (2009) identify these variables as profitability, firm size, the un-weighted market-to-book ratio and asset tangibility. A number of studies, including those of Baker and Wurgler (2002), Bruinshoofd and De Haan (2012), De Bie and De Haan (2007), Mahajan and Tartaroglu (2008) and Xu (2009) use these firm-specific variables, together with an appropriate market timing measure, to test for the validity of the market timing theory. The current study also used these variables, together with an appropriate market timing measure, to test for the validity of the market timing theory in the context of South African non-financial firms.

The Effect of Firm Profitability, Firm Size, the Un-Weighted Market-To-Book Ratio and Asset Tangibility on Leverage

Barclay and Smith (2005) contend that profitable firms tend to be large and mature, and have a high stocks of tangibles. These firms, however, have limited growth options and hence have lower capital expenditures. Profitable firms have a higher propensity towards generating excess free cash flows (Jensen, 1986). According to Talberg, Winge, Frydenberg and Westgaard (2008), a firm's size is positively correlated with its stock of tangibles. Asset tangibility is a direct measure of the collateral amount that a firm can offer to its bondholders (Leland, 1994). Firms with higher stocks of tangibles offer lenders increased security, which in turn increases the firms' debt capacities and credit ratings which, lower their costs of debt (Giambona, Mello \& Riddiough, 2012). These features of large and profitable firms combine to give them higher credit ratings and lower bankruptcy costs, and this makes borrowing a more attractive option to them. On the other hand, low growth options reduce a firm's non-debt tax shields, which, according to De Angelo and Masulis (1980), are perfect substitutes for the interest tax shields. This strengthens the firm's case for increasing its debt. These characterises of large, mature and profitable firms have different implications for both the trade-off and pecking order theories.

According to the pecking order theory of Myers and Majluf (1984), the main determinant of a firm's leverage is its internal funds deficiency. This deficiency is financed by raising external capital in a pecking order that is, debt is raised first, then hybrid securities, and lastly equity (Myers, 1984). Large, mature and profitable firms with reduced growth rates have more internal funds available, and this lowers their internal financing deficits, which in turn reduce their requirements for external finance (Barclay \& Smith, 2005). The pecking order theory therefore predicts that large, mature and profitable firms will have lower debt ratios, as they face reduced internal fund deficiencies or have no internal funds deficiencies. The theory therefore predicts a negative correlation between leverage and the variables firm profitability and asset tangibility. According to the pecking order theory, leverage is positively correlated to firm growth rate.

On the other hand, the trade-off theory contends that, large and profitable firms face increased tax bills deriving from reduced non-debt tax shields. As large and profitable firms are likely to produce excess free cash flows, the agency costs theory states that these firms face higher agency costs which derive from the excess free cash flows. (Drobetz \& Wanzenried, 2006 and Frank \& Goyal, 2009). The trade-off theory contends that the problem of an increased tax bill can be resolved by increasing the firm's debt, which in turn increases the interest tax shield and thus lower the corporate tax payable. A firm can increase its debt by substituting the excess internal equity with debt. The excess equity is returned to shareholders in the form of increased dividends and share buybacks (Barclay \& Smith, 2005). The increased debt interest charge reduces the firm's corporate tax bill while maximising its value through the increased debt interest tax shield. Furthermore, increased debt reduces the firm's agency costs of free cash flow (Jensen 1986). The trade-off theory therefore predicts a positive correlation between leverage and the variables asset tangibility, firm size and profitability. It predicts a negative correlation between leverage and firm growth rate.

The dependent variables uses in this study are defined as follows. The (MDR) is the total interest-bearing debt scaled up by the sum of the total debt and the firm market capitalisation and the (BDR) is the total interest- 
bearing debt scaled up by the total assets. The firm-specific explanatory variables are defined as follows. Firm profitability (Profitability) is the earnings before interest, tax, depreciation and amortisation (EBITDA) and is expressed as a fraction of total assets (TA). Firm size (Size) is the natural logarithm of the total assets. Asset tangibility (Tangibility) is the fixed assets scaled up by the total assets. The un-weighted market-to-book ratio (MTB) is the sum of the market value of equity, book value of preference shares and the book value of total debt, less the deferred taxes; this is scaled up by the total assets.

The inclusion of the un-weighted market-to-book variable in the regression model also provides a control for the cross-sectional variation in the level of market-to-book and this leaves only the residual influence of the past within-firm variation in the market-to-book ratio for the $E F W A M B_{t}^{B W}$.

\section{Hypotheses}

The hypotheses developed above can be summarised as follows:

H1: Market Timing Behaviour: Firms time the market in their debt-equity issuance decisions and do not consecutively rebalance their capital structures. Thus there is a significant negative correlation between leverage and the $E F W A M B_{t}^{B W}$. A significant negative correlation between leverage and $E F W A M B$ confirms the validity of the market timing theory, whilst a positive correlation or insignificant negative correlation validates the static trade-off theory.

H2: Firm-specific Determinants of Leverage: The hypotheses for the correlations between leverage and firmspecific factors are summarised in Table 2 below:

Table 2. Predicted Correlation between Leverage and Firm-Specific Variables

\begin{tabular}{|c|c|c|}
\hline \multirow{2}{*}{ Firm-Specific Variable } & \multicolumn{2}{|c|}{ Theory Prediction } \\
\hline & Trade-off & Pecking Order \\
\hline Profitability & + & - \\
\hline Size & + & - \\
\hline Tangibility & + & - \\
\hline Growth rate (MTB) & - & $+/-$ \\
\hline
\end{tabular}

$+:$ positive correlation between leverage and the variable

$-:$ negative correlation between leverage and the variable.

H3: SOA towards Target Leverage: The market timing theory hypothesises that firms do not have target leverage ratios and hence will have zero SOA.

\section{Data Sources}

\section{DATA AND METHODOLOGY}

The data sample consisted of 143 JSE-listed non-financial firms with complete data for eight or more consecutive years during the period 2003 to 2012. The unbalanced panel was constructed from data drawn from standardised annual financial statements that were obtained from the McGregorBFA database. The total number of observations for the period was 1,430. In order to allow for a comparison of the results of this study with those of the US, Canada, Japan, France, Germany, Italy, UK and the rest of continental Europe, this study adopted the methodology used by Bruinshoofd and De Haan (2012) and Mahajan and Tartaroglu (2008). It did however extend the methodologies of these studies to include the test for the impact of the Baker and Wurgler (2002) market timing measure on the SOA towards the target leverage.

Regression Model

Following Baker and Wurgler (2002), Bruinshoofd and De Haan (2012) and Mahajan and Tartaroglu (2008), the basic regression model was specified as: 


$$
L e v_{i, t+1}=\gamma_{1} E F W A M B_{t}^{B W}+\gamma_{2}\left(\frac{E B I T D A}{T A}\right)_{t}+\gamma_{3} \operatorname{Ln}(T A)_{t}+\gamma_{4}\left(\frac{F A}{T A}\right)_{t}+\beta_{5} M T B_{t}+c_{i}+\varepsilon_{i, t+1}
$$

Where: $\operatorname{Lev}_{i, t+1}$ is the firm's debt ratio measured by either the BDR or the MDR at $i, t+1 ; i$ denotes a particular firm; $t$ is the current year; $t+1$ is the next year; $\gamma_{1}, \gamma_{2}, \gamma_{3}, \gamma_{4}$ and $\gamma_{5}$ are coefficient vectors; $c_{i}$ denotes the firm fixed effect and $\varepsilon_{i, t+1}$ is an error term.In this study, $E F W A M B_{t}^{B W}$ was substituted by $E F W A M B_{t}^{B D}$ and the resulting model was specified as:

$$
\operatorname{Lev}_{i, t+1}=\gamma_{1} \boldsymbol{X}_{t}+\gamma_{2} E F W A M B_{t}^{B D}+c_{i}+\varepsilon_{i, t+1}
$$

Where $\boldsymbol{X}_{i, t}$ is a vector of the firm-specific variables contained in model 1.

According to the dynamic trade-off theory, firms have target debt ratios towards which they actively adjust at a given speed. The active adjustment towards a target debt ratio assumes a perfect capital market, which implies that firms will frequently and fully adjust to their chosen target ratios. However, in practice, firms face information asymmetries, transaction costs and adjustment costs, and this implies that they will infrequently and partially adjust their capital structures towards their predetermined leverage ratios. A firm's target leverage, $L e v_{i, t+1}^{*}$, is given by:

$$
\operatorname{Lev}_{i, t+1}^{*}=\boldsymbol{X}_{i, t} \gamma
$$

Where $\gamma$ is a coefficient vector.

The firm's leverage partial adjustment model is specified as:

$$
\operatorname{Lev}_{i, t+1}-\operatorname{Lev}_{i, t}=\left(\operatorname{Lev}_{i, t+1}^{*}-\operatorname{Lev}_{i, t}\right)+\varepsilon_{i, t+1}
$$

Substituting (6) into (7) and simplifying the equation yields a partial adjustment model that can be used to estimate the firm's SOA towards the target leverage that is:

$$
\operatorname{Lev}_{i, t+1}=(1-\lambda) \operatorname{Lev}_{i, t}+\lambda\left(\boldsymbol{X}_{i, t} \gamma\right)+c_{i}+\varepsilon_{i, t+1}
$$

Where $\lambda$ denotes the SOA towards the target leverage and $c_{i}$ is the time-invariant unobserved variable (firm-fixed effect).

For the dynamic trade-off theory hypothesis to hold, some of the elements of the coefficient vector must be different from zero that is $\gamma \neq 0$. In cases where $\lambda=0$, it means that the SOA is zero implying that firms have no target leverage ratios. If $\lambda=1$, it means that the firm immediately adjusts towards its target debt ratio. It is also possible to get negative values of $\lambda$. The negative SOA means that the firm over-adjusts its leverage.

The partial adjustment model can be extended to include the market timing measure. The extended partial adjustment model is therefore:

$$
\operatorname{Lev}_{i, t+1}=(1-\lambda) L e v_{i, t}+\lambda\left(\boldsymbol{X}_{i, t} \gamma_{1}\right)+\lambda \gamma_{2} E F W A M B_{t}^{B D}+c_{i}+\varepsilon_{i, t+1}
$$

This is the basic regression model and is labelled regression model 1 . The alternative partial adjustment model only uses the firm-specific variables with no market timing measures. This is expressed as:

$$
\operatorname{Lev}_{i, t+1}=(1-\lambda) L e v_{i, t}+\lambda\left(\boldsymbol{X}_{i, t} \gamma\right)+c_{i}+\varepsilon_{i, t+1}
$$

This is regression model 2.

The study used regression model 1 to test for the validity of the market timing and dynamic trade-off theories and to estimate the SOA towards the target leverage. Regression model 2 was used to test what impact 
excluding the market timing measure has on the firm's SOA towards the target leverage. The random effects Tobit maximum likelihood estimator was used to fit both regression models. This estimator is an equivalent of the doublecensored dynamic panel data with a fractional dependent variable (DPF) estimator proposed by Elsas and Florysiak (2011) and Elsas and Florysiak (2013). Unlike the much recommended Blundell and Bond (1998) system generalised method of moments (GMM), the bias-corrected least squares dummy variable (LSDVC) and the long difference estimators, the random effects Tobit/DPF maximum likelihood estimator is unbiased, is consistent in the context of unbalanced dynamic panel data with a fractional dependent variable, and also accounts for firm-fixed effects. Leverage ratios are fractional in nature; they occur between 0 and 1 . This makes the random effects Tobit maximum likelihood estimator the most suitable estimator for use in this study. The estimator was implemented in Stata using the xttobit command with censors specified as 0 (minimum) and 1 (maximum).

\section{RESULTS}

\section{Summary Statistics}

The summary statistics of the sample are presented in Table 3. The sample's median BDR of 0.1171 is much lower than those of the firms in the US (0.546), UK (0.538) and continental Europe (0.639) (Bruinshoofd \& De Haan (2012), De Bie \& De Haan, 2007 and Mahajan \& Tartaroglu, 2008). The median MDR is 0.0940. These statistics confirm the conservative use of debt by South African non-financial firms. This implies that the South African firms rely more on equity for their financing requirements. With a median profitability of $19.44 \%$ (mean $20.00 \%$ ), the South African firms are more profitable than their US (median 13.23\%), UK (median 12.69\%), Italian (median 9.39\%), German (median 11.86\%) and French (median 11.49\%) counterparts. This further implies that the South African firms are likely to rely more on internal equity than on external finance, and hence have lower median leverage ratios.

The median growth rate which is measured by the market-to-book ratio, is much lower for the South African firms tested (median 1.0888) than for the firms from the US (median 1.49), the UK (median 1.33), Italy (median 1.16), Germany (median 1.14) and France (median 1.19). The median value of the market timing measure, the EFWAMB BD , is 0.010 for the South African firms, and this is much lower than those of the firms in the US (1.031), the UK (1.015) and continental Europe (1.003) (Bruinshoofd \& De Haan, 2012). In accordance with the market timing theory, the lower market-to-book ratio and the lower market timing measures suggest that South African non-financial firms are less likely to time the market in their security issuance decisions. These firms hold higher stocks of tangibles (median 29.21\%) than the US (median 24.929\%), Italian (median 21.74\%), German (median 23.10\%) and French (median 17.51\%) firms. The tangibility of the South African firms tested is however lower than that of the UK firms (median 31.84\%) (Mahajan \&Tartaroglu, 2008). It should be noted that the size factors cannot be compared with the statistics from other countries, as the currencies are different.

The Table 3 Summary Statistics 2003-2012 data sample consisted of 143 JSE-listed non-financial firms with complete data for eight or more consecutive years during the period 2003 to 2012 . The unbalanced panel was constructed from data drawn from standardised annual financial statements which were obtained from the McGregorBFA database. The total number of observations for the period was 1, 430. To eliminate outlier observations and the most extremely misrecorded data, all variables were winsorised at the 1st and 99th percentiles. Following Baker and Wurgler (2002:12), EFWAMB $B_{t}^{B W}, E E W A M B_{t}, D W A M B_{t}$, and $E F W A M B_{t}^{B D}$ values greater than 10 were dropped and negative $E F W A M B_{t}^{B W}, E E W A M B_{t}, D W A M B_{t}$, and $E F W A M B_{t}^{B D}$ values were reset to zero.

Market-to-debt ratio (MDR): the total interest-bearing debt scaled up by the sum of the total debt and the firm market capitalisation.

Book-to-debt ratio (BDR): the total interest-bearing debt scaled up by the total assets.

Firm profitability (Profitability): the earnings before interest, tax, depreciation and amortisation $(\boldsymbol{E B I T D A})$ as a fraction of the total assets $(\boldsymbol{T A})$. 
Firm size (Size): the natural logarithm of the total assets.

Asset tangibility (Tangibility): the fixed assets scaled up by the total assets.

Un-weighted market-to-book ratio (MTB): the sum of the market value of equity, the book value of preference shares and the book value of the total debt, less the deferred taxes; this was scaled up by the total assets.

Weighted market-to-book ratio: the market timing measures which are defined as follows:

$$
\begin{aligned}
& E F W A M B_{t}^{B W} \equiv \sum_{s=1}^{t-1} \frac{e_{S}+l t d_{s}}{\sum_{r=1}^{t-1} e_{r}+l t d_{r}} \times M B_{s} ; \quad E E W A M B_{t} \equiv \frac{1}{\overline{M B}} \sum_{s=1}^{t-1} \frac{e_{s}}{\sum_{r=1}^{t-1} e_{r}} \times M B_{s} ; \\
& D W A M B_{t} \equiv \frac{1}{\overline{M B}} \sum_{s=1}^{t-1} \frac{l t d_{s}}{\sum_{r=1}^{t-1} l t d_{r}} \times M B_{s} \text { and } E F W A M B_{t}^{B D} \equiv \frac{1}{\overline{M B}} \sum_{s=1}^{t-1} \frac{e_{s}+l t d_{s}}{\sum_{r=1}^{t-1} e_{r}+l t d_{r}} \times M B_{S}
\end{aligned}
$$

Where $e$ and ltd denote the net equity and the long-term debt issuances respectively; $M B$ is the un-weighted market-to-book ratio; suffix $s$ represents the issuances from a specific year; and $r$ represents issuances for the total period. Equity and debt issuances are respectively defined as a change (increase) in the book value of the share capital and change (increase) in the book value of the debt.

\begin{tabular}{|c|c|c|c|c|c|c|c|c|}
\hline Variable & No. Obs. & Mean & Median & Std. Dev. & Min. & Max. & Skewness & Kurtosis \\
\hline MDR & 1,277 & 0.1716 & 0.0940 & 0.2037 & 0.0000 & 0.9138 & 1.5880 & 5.4508 \\
\hline BDR & 1,287 & 0.1909 & 0.1171 & 0.2801 & 0.0000 & 1.0000 & 5.8844 & 71.6323 \\
\hline Profitability & 1,430 & 0.2000 & 0.1944 & 0.1186 & 0.0193 & 0.4023 & 0.1693 & 2.0518 \\
\hline Size & 1,430 & 14.3066 & 14.4855 & 2.0317 & 10.8046 & 17.2895 & -0.2129 & 1.9738 \\
\hline Tangibility & 1,430 & 0.3240 & 0.2921 & 0.2278 & 0.0435 & 0.7104 & 0.3895 & 1.8283 \\
\hline MTB & 1,419 & 1.3374 & 1.0888 & 0.8422 & 0.3947 & 3.0554 & 0.8413 & 2.5400 \\
\hline$E F W A M B_{t}^{B W}$ & 1,427 & 0.1647 & 0.0129 & 0.2606 & 0.0000 & 0.7729 & 1.4847 & 3.6824 \\
\hline$E E W A M B_{t}$ & 1,385 & 0.0721 & 0.0000 & 0.1273 & 0.0000 & 0.3767 & 1.6250 & 4.0351 \\
\hline$D W A M B_{t}$ & 1,416 & 0.1215 & 0.0019 & 0.1950 & 0.0000 & 0.5781 & 1.5067 & 3.7514 \\
\hline$E F W A M B_{t}^{B D}$ & 1,428 & 0.1445 & 0.0104 & 0.2308 & 0.0000 & 0.6936 & 1.5386 & 3.8764 \\
\hline
\end{tabular}

Table 3. Summary Statistics 2003-2012

\section{Empirical Results}

Regression Model Results

The empirical results for regression model 1 are contained in Table 4.

\section{Market Timing Behaviour}

The results indicate that the modified market timing measure, $E F W A M B_{t}^{B D}$, is positively related to both the MDR and the BDR. The correlation is significant for the MDR. The market timing hypothesis is thus rejected in the case of South African non-financial firms listed on the JSE. The firms do not time the market in issuing securities. The market timing theory is therefore not a good descriptor of corporate financing in South Africa.

\section{Firm-Specific Variables}

Profitability: The results indicate that in both the MDR and the BDR regressions, profitability is inversely related to leverage and is a significant predictor of leverage. Its significance to explain leverage increases with the study's time period and sample size. The results imply that, for non-financial firms listed on the JSE, leverage decreases with an increase in firm profitability. Profitable firms have a higher propensity towards retaining more profits to finance their future operations and thus depend less on external finance. According to the pecking order theory, increased profitability reduces a firm's internal funds deficiency and hence reduces its need to raise external finance. As firms are more likely to firstly raise debt to cover their internal funds deficiencies, increased profitability 
and earnings retention effectively reduce the firm's leverage. The study's finding relating to profitability is thus consistent with the pecking order theory.

Size, tangibility and firm growth rate

The study found that size and tangibility are positively related to both the MDR and the BDR, and the correlation significance increases with an increase in the time period and an increase in the sample size of the study. Tangibility is a significant predictor of the MDR but a weak predictor of the BDR. Furthermore, firm growth rate is negatively correlated to both the MDR and the BDR. The results imply that large firms with higher stocks of tangibles and reduced growth rates have higher debt ratios. Conversely, smaller firms with lower stocks of tangibles and increased growth rate have lower debt ratios. These findings validate the trade-off theory. According to Barclay and Smith (2005), large firms tend to be mature and profitable, and have high stocks of tangibles. These characteristics enhance the firms' debt capacities and credit ratings, thus making borrowing a more attractive option. These firms, however, have less growth options and hence lower capital expenditures; which effectively reduces their non-debt tax shields (NDTSs). Moyo et al (2013) and Ramjee and Gwatidzo (2012) documented similar findings on JSE-listed firms. 
Table 4 Regression model 1 results:

$\operatorname{Lev}_{i, t+1}=(1-\lambda) \operatorname{Lev}_{i, t}+\lambda\left(\boldsymbol{X}_{i, t} \gamma_{1}\right)+\lambda \gamma_{2} E F W A M B_{t}^{B D}+c_{i}+\varepsilon_{i, t+1}$

Where $\lambda$ is the SOA towards the target leverage, $\boldsymbol{X}_{i, t}$ is a vector of firm characteristics that determine the target leverage and the SOA towards the target leverage, $\gamma_{1}$ and $\gamma_{2}$ are coefficient vectors, $c_{i}$ is the time-invariant unobserved variable (firm fixed effect) and $\varepsilon_{i, t+1}$ is an error term. The vector $\boldsymbol{X}_{i, t}$ consists of the variables: profitability, size, tangibility and the un-weighted market-to-book ratio, and these are defined in Table 3. EFWAMB $B_{t}^{B D}$ is the Bruinshoofd and De Haan (2012) market timing measure, which is also defined in Table 3. T-statistics are reported in parentheses. The markings $* * *, * *$ and $*$ on coefficient estimates denote significant differences from zero at the levels of $1 \%, 5 \%$ and $10 \%$ respectively. The implied half-life is calculated as: half - life $=\log (0.5) / \log (1-\lambda)$. Model specifications are shown under fit statistics.

Table 4. The Effects of Historical Weighted Market-to-Book Ratios in the MDR and the BDR Capital Structure Regressions

\begin{tabular}{|c|c|c|c|c|c|c|c|c|c|c|c|}
\hline & \multicolumn{5}{|c|}{ Variables } & \multicolumn{3}{|c|}{ Speed of Adjustment } & \multicolumn{3}{|c|}{ Fit Statistics } \\
\hline & Profitability & Size & Tangibility & МТВ & $E F W A M B_{t}^{B D}$ & $\begin{array}{c}\text { Lev_t-1 } \\
\text { Coefficient }\end{array}$ & $\operatorname{SOA}(\lambda)$ & $\begin{array}{c}\text { Half-life } \\
\text { (years) }\end{array}$ & Obs & Wald Chi2 & Prob $>$ Chi2 \\
\hline \multicolumn{12}{|c|}{ Market Leverage (MDR) } \\
\hline 2003-2007 & $\begin{array}{c}-0.2158^{* * * *} \\
(-3.38)\end{array}$ & $\begin{array}{c}0.0038 \\
(1.09)\end{array}$ & $\begin{array}{l}0.0505 \\
(1.54)\end{array}$ & $\begin{array}{c}-0.0037 \\
(-0.39)\end{array}$ & $\begin{array}{c}0.0580 * * \\
(2.67)\end{array}$ & $\begin{array}{c}0.6289 * * * \\
(9.52)\end{array}$ & $37.11 \%$ & 1.49 & 695 & 207.34 & 0.0000 \\
\hline $2004-2008$ & $\begin{array}{c}-0.1662 * \\
(-2.55)\end{array}$ & $\begin{array}{c}0.0104^{*} \\
(2.57)\end{array}$ & $\begin{array}{l}0.0681 \\
(1.89)\end{array}$ & $\begin{array}{c}-0.0070 \\
(-0.69)\end{array}$ & $\begin{array}{c}0.0507^{*} \\
(2.47) \\
\end{array}$ & $\begin{array}{c}0.5973^{* * *} \\
(9.89)\end{array}$ & $40.27 \%$ & 1.35 & 695 & 216.96 & 0.0000 \\
\hline $2005-2009$ & $\begin{array}{c}-0.1695^{* *} \\
(-2.68)\end{array}$ & $\begin{array}{l}0.0087 \\
(1.90)\end{array}$ & $\begin{array}{l}0.0649 \\
(1.67)\end{array}$ & $\begin{array}{c}-0.0129 \\
(-1.29) \\
\end{array}$ & $\begin{array}{c}0.0478^{* *} \\
(2.59)\end{array}$ & $\begin{array}{c}0.5054^{* * *} \\
(7.00)\end{array}$ & $49.46 \%$ & 1.02 & 698 & 131.63 & 0.0000 \\
\hline $2006-2010$ & $\begin{array}{c}-0.1633^{* *} \\
(-2.59) \\
\end{array}$ & $\begin{array}{l}0.0095 \\
(1.92) \\
\end{array}$ & $\begin{array}{c}0.0989^{*} \\
(2.49) \\
\end{array}$ & $\begin{array}{c}-0.0114 \\
(-1.24) \\
\end{array}$ & $\begin{array}{c}0.0564^{* *} \\
(3.01)\end{array}$ & $\begin{array}{c}0.4425^{* * *} \\
(7.08)\end{array}$ & $55.75 \%$ & 0.85 & 701 & 132.59 & 0.0000 \\
\hline $2007-2011$ & $\begin{array}{c}-0.1345^{*} \\
(-2.40) \\
\end{array}$ & $\begin{array}{l}0.0017 \\
(0.59) \\
\end{array}$ & $\begin{array}{c}0.0576^{*} \\
(2.26) \\
\end{array}$ & $\begin{array}{c}-0.0048 \\
(-0.65) \\
\end{array}$ & $\begin{array}{c}0.0989^{* * *} \\
(3.86)\end{array}$ & $\begin{array}{c}0.8055^{* * *} \\
(14.54)\end{array}$ & $19.45 \%$ & 3.20 & 704 & 402.21 & 0.0000 \\
\hline $2008-2012$ & $\begin{array}{c}-0.1437^{*} \\
(-2.54) \\
\end{array}$ & $\begin{array}{l}0.0022 \\
(0.71) \\
\end{array}$ & $\begin{array}{c}0.0614^{*} \\
(2.47) \\
\end{array}$ & $\begin{array}{c}-0.0049 \\
(-0.60) \\
\end{array}$ & $\begin{array}{c}0.0881^{* *} \\
(2.77) \\
\end{array}$ & $\begin{array}{c}0.8008^{* * * *} \\
(25.87)\end{array}$ & $19.92 \%$ & 3.12 & 564 & $1,026.59$ & 0.0000 \\
\hline Full Sample & $\begin{array}{c}-0.2191 * * * \\
(-4.47) \\
\end{array}$ & $\begin{array}{c}0.0073^{*} \\
(2.16) \\
\end{array}$ & $\begin{array}{c}0.0782^{* *} \\
(2.76) \\
\end{array}$ & $\begin{array}{c}-0.0078 \\
(-1.05) \\
\end{array}$ & $\begin{array}{c}0.0626^{* * * *} \\
(3.48)\end{array}$ & $\begin{array}{c}0.5820^{* * * *} \\
(16.18)\end{array}$ & $41.80 \%$ & 1.28 & 1,259 & 499.07 & 0.0000 \\
\hline \multicolumn{12}{|c|}{ Book Leverage ( BDR ) } \\
\hline 2003-2007 & $\begin{array}{c}-0.2283^{* * *} \\
(-3.33) \\
\end{array}$ & $\begin{array}{c}0.0152^{* *} \\
(3.09) \\
\end{array}$ & $\begin{array}{c}0.0923^{*} \\
(2.19) \\
\end{array}$ & $\begin{array}{c}-0.0019 \\
(-0.19) \\
\end{array}$ & $\begin{array}{l}0.0220 \\
(1.06) \\
\end{array}$ & $\begin{array}{c}0.4065^{* * *} \\
(9.73) \\
\end{array}$ & $53.35 \%$ & 0.77 & 706 & 183.39 & 0.0000 \\
\hline 2004-2008 & $\begin{array}{c}-0.1283^{*} \\
(-2.07) \\
\end{array}$ & $\begin{array}{c}0.0145^{* * * *} \\
(3.82)\end{array}$ & $\begin{array}{c}0.0906^{* * *} \\
(2.69) \\
\end{array}$ & $\begin{array}{c}-0.0006 \\
(-0.06) \\
\end{array}$ & $\begin{array}{l}0.0014 \\
(0.07) \\
\end{array}$ & $\begin{array}{c}0.5906^{* * *} \\
(12.90) \\
\end{array}$ & $40.94 \%$ & 1.32 & 705 & 311.61 & 0.0000 \\
\hline $2005-2009$ & $\begin{array}{c}-0.1235^{*} \\
(-2.08)\end{array}$ & $\begin{array}{c}0.0145^{* *} \\
(2.92)\end{array}$ & $\begin{array}{c}0.1240^{* *} \\
(3.03)\end{array}$ & $\begin{array}{l}0.0035 \\
(0.39)\end{array}$ & $\begin{array}{l}0.0116 \\
(0.71)\end{array}$ & $\begin{array}{c}0.4352^{* * * *} \\
(9.45)\end{array}$ & $56.48 \%$ & 0.83 & 707 & 192.67 & 0.0000 \\
\hline $2006-2010$ & $\begin{array}{c}-0.1635^{* *} \\
(-2.71)\end{array}$ & $\begin{array}{l}0.0061 \\
(1.57)\end{array}$ & $\begin{array}{c}0.0689 * \\
(2.11)\end{array}$ & $\begin{array}{l}0.0111 \\
(1.37)\end{array}$ & $\begin{array}{l}0.0086 \\
(0.44)\end{array}$ & $\begin{array}{c}0.6111^{* * * *} \\
(9.08)\end{array}$ & $38.89 \%$ & 1.41 & 708 & 143.38 & 0.0000 \\
\hline $2007-2011$ & $\begin{array}{l}-0.1167 \\
(-1.93) \\
\end{array}$ & $\begin{array}{c}0.0093^{*} \\
(2.47) \\
\end{array}$ & $\begin{array}{l}0.0571 \\
(1.86) \\
\end{array}$ & $\begin{array}{c}0.1380 \\
(1.68) \\
\end{array}$ & $\begin{array}{l}0.0059 \\
(0.24) \\
\end{array}$ & $\begin{array}{c}0.6496^{* * * *} \\
(8.96)\end{array}$ & $35.04 \%$ & 1.61 & 709 & 139.79 & 0.0000 \\
\hline $2008-2012$ & $\begin{array}{c}-0.1454 * * \\
(-2.74)\end{array}$ & $\begin{array}{l}0.0048 \\
(1.67) \\
\end{array}$ & $\begin{array}{l}0.0457 \\
(1.95) \\
\end{array}$ & $\begin{array}{l}0.0132 \\
(1.82) \\
\end{array}$ & $\begin{array}{c}-0.0048 \\
(-0.16) \\
\end{array}$ & $\begin{array}{c}0.8582^{* * * *} \\
(32.10)\end{array}$ & $14.18 \%$ & 4.53 & 568 & $1,215.63$ & 0.0000 \\
\hline Full Sample & $\begin{array}{c}-0.1971 * * * \\
(-3.97)\end{array}$ & $\begin{array}{c}0.0152^{* * *} \\
(3.85)\end{array}$ & $\begin{array}{c}0.0830^{*} \\
(2.47) \\
\end{array}$ & $\begin{array}{c}0.0042 \\
(0.58) \\
\end{array}$ & $\begin{array}{l}0.0142 \\
(0.84)\end{array}$ & $\begin{array}{c}0.4718^{* * *} \\
(17.98)\end{array}$ & $52.82 \%$ & 0.92 & 1,274 & 500.69 & 0.0000 \\
\hline
\end{tabular}

Copyright by author(s); CC-BY 


\section{Target Speed of Adjustment}

In all the tests, the firms exhibit a positive and significant SOA. These results confirm that the sampled firms have target leverage debt ratios which they continuously adjust towards. The SOA increases with time and sample size indicating that the full SOA is the least biased. The true SOA for the sample is $41.80 \%$ (half-life of 1.28 years) for the MDR and $52.82 \%$ (half-life of 0.92 years) for the BDR. This means that, in the case of the MDR, $41.80 \%$ of the target deviation spread is covered in one year and it takes 1.28 year to cover $50 \%$ of the target deviation spread. The target SOA results validate the dynamic trade-off theory and reject the market timing and pecking order theories. Using the same random effects Tobit estimator, Moyo et al (2013) documented a target SOA of $42.44 \%$ (MDR) and $57.64 \%$ (BDR) for JSE-listed manufacturing, mining and retail firms. The results of the current study are therefore consistent with these findings.

Regression Model 2 Results

The results are contained in Table 5.

Normal Capital Structure Regressions Results

The pattern of the results is similar to that of regression model 1 discussed above; there are no significant differences. Profitability and growth rate were found to be inversely proportional to the MDR and the BDR, whilst size and tangibility are positively correlated to the MDR and the BDR. Profitability, size and tangibility are significant determinants of leverage. The pecking order theory is validated by the negative correlation between leverage and profitability. The correlation results for size, tangibility and growth rate all validate the trade-off theory. The results concerning the SOA towards the target leverage also follows the same pattern exhibited in regression model 1. The true SOA for the sample is $41.92 \%$ (half-life of 1.28 years) for the MDR and $52.66 \%$ (half-life of 0.93 years) for the BDR. The results imply that the impact of the market timing measure is negligible in determining correlations and the SOA. The effects of market timing are thus negligible in the context of South African non-financial firms. These results confirm the rejection of the market timing theory in the case of non-financial firms listed on the JSE. 
Table 5 Regression model 2 results:

$\operatorname{Lev}_{i, t+1}=(1-\lambda) \operatorname{Lev}_{i, t}+\lambda\left(\boldsymbol{X}_{i, t} \gamma\right)+c_{i}+\varepsilon_{i, t+1}$

Where $\lambda$ is the SOA towards the target leverage, $\boldsymbol{X}_{i, t}$ is a vector of firm characteristics that determine the target leverage and the SOA towards the target leverage, $\gamma$ is a coefficient vector, $c_{i}$ is the time-invariant unobserved variable (firm fixed effect) and $\varepsilon_{i, t+1}$ is an error term. The vector $\boldsymbol{X}_{i, t}$ consists of the variables: profitability, size, tangibility and the un-weighted market-to-book ratio, and these are defined in Table 3 . T-statistics are reported in parentheses. The markings $* * *, * *$ and $*$ on coefficient estimates denote significant differences from zero at the levels of $1 \%, 5 \%$ and $10 \%$ respectively. The implied half-life is calculated as: half - life $=\log (0.5) / \log (1-\lambda)$. Model specifications are shown under fit statistics.

\begin{tabular}{|c|c|c|c|c|c|c|c|c|c|c|}
\hline \multicolumn{5}{|c|}{ Variables } & \multicolumn{3}{|c|}{ Speed of Adjustment } & \multicolumn{3}{|c|}{ Fit Statistics } \\
\hline & Profitability & Size & Tangibility & MTB & $\begin{array}{c}\text { Lev_t-1 } \\
\text { Coefficient }\end{array}$ & $\operatorname{SOA}(\lambda)$ & $\begin{array}{c}\text { Half-life } \\
\text { (years) }\end{array}$ & Obs & $\begin{array}{l}\text { Wald } \\
\text { Chi2 }\end{array}$ & $\begin{array}{c}\text { Prob>> } \\
\text { Chi2 }\end{array}$ \\
\hline \multicolumn{11}{|c|}{ Market Leverage (MDR) } \\
\hline 2003-2007 & $\begin{array}{l}-0.2246 * * * \\
(-3.42)\end{array}$ & $\begin{array}{l}0.0040 \\
(1.11)\end{array}$ & $\begin{array}{l}0.0510 \\
(1.51)\end{array}$ & $\begin{array}{l}-0.0002 \\
(-0.02)\end{array}$ & $\begin{array}{c}0.6184 * * * \\
(9.70)\end{array}$ & $38.16 \%$ & 1.44 & 697 & 208.05 & 0.0000 \\
\hline 2004-2008 & $\begin{array}{l}-0.1771^{* *} \\
(-2.67)\end{array}$ & $\begin{array}{l}0.0114 * * \\
(2.70)\end{array}$ & $\begin{array}{l}0.0709 \\
(1.91)\end{array}$ & $\begin{array}{l}-0.0030 \\
(-0.29)\end{array}$ & $\begin{array}{c}0.5859 * * * \\
(9.93)\end{array}$ & $41.41 \%$ & 1.30 & 797 & 216.97 & 0.0000 \\
\hline 2005-2009 & $\begin{array}{l}-0.1728^{* *} \\
(-2.69)\end{array}$ & $\begin{array}{l}0.0100^{*} \\
(2.04)\end{array}$ & $\begin{array}{l}0.0703 \\
(1.74)\end{array}$ & $\begin{array}{l}-0.0094 \\
(-0.93)\end{array}$ & $\begin{array}{c}0.4744^{* * *} \\
(7.06)\end{array}$ & $52.56 \%$ & 0.93 & 697 & 128.00 & 0.0000 \\
\hline 2006-2010 & $\begin{array}{l}-0.1608^{*} \\
(-2.53)\end{array}$ & $\begin{array}{l}0.0106^{*} \\
(2.08)\end{array}$ & $\begin{array}{l}0.1084 * * \\
(2.67)\end{array}$ & $\begin{array}{l}-0.0074 \\
(-0.80)\end{array}$ & $\begin{array}{c}0.4201^{* * * *} \\
(6.88)\end{array}$ & $57.99 \%$ & 0.80 & 702 & 124.30 & 0.0000 \\
\hline $2007-2011$ & $\begin{array}{l}-0.1227^{*} \\
(-2.21)\end{array}$ & $\begin{array}{c}0.0027 \\
(0.97) \\
\end{array}$ & $\begin{array}{l}0.0588^{*} \\
(2.35) \\
\end{array}$ & $\begin{array}{l}-0.0044 \\
(-0.60) \\
\end{array}$ & $\begin{array}{c}0.8147 * * * \\
(15.22) \\
\end{array}$ & $18.53 \%$ & 3.38 & 704 & 401.28 & 0.0000 \\
\hline 2008-2012 & $\begin{array}{l}-0.1400^{*} \\
(-2.46)\end{array}$ & $\begin{array}{l}0.0032 \\
(1.05)\end{array}$ & $\begin{array}{l}0.0641^{*} \\
(2.55)\end{array}$ & $\begin{array}{l}-0.0051 \\
(-0.61)\end{array}$ & $\begin{array}{c}0.7983^{* * * *} \\
(25.61)\end{array}$ & $20.17 \%$ & 3.08 & 564 & $1,004.77$ & 0.0000 \\
\hline Full Sample & $\begin{array}{l}-0.2225 * * * \\
(-4.50)\end{array}$ & $\begin{array}{l}0.0078^{*} \\
(2.29)\end{array}$ & $\begin{array}{l}0.0787^{* *} \\
(2.74) \\
\end{array}$ & $\begin{array}{c}-0.0041 \\
(-0.54) \\
\end{array}$ & $\begin{array}{c}0.5808^{* * *} \\
(16.18) \\
\end{array}$ & $41.92 \%$ & 1.28 & 1,261 & 483.66 & 0.0000 \\
\hline \multicolumn{11}{|c|}{ Book Leverage ( BDR ) } \\
\hline 2003-2007 & $\begin{array}{c}-0.2295 * * * \\
(-3.36)\end{array}$ & $\begin{array}{c}0.0152^{* *} \\
(3.10)\end{array}$ & $\begin{array}{c}0.0907^{*} \\
(2.15) \\
\end{array}$ & $\begin{array}{l}-0.0004 \\
(-0.04) \\
\end{array}$ & $\begin{array}{c}0.4085^{* * * *} \\
(9.89) \\
\end{array}$ & $59.15 \%$ & 0.77 & 708 & 183.08 & 0.0000 \\
\hline 2004-2008 & $\begin{array}{c}-0.1264^{*} \\
(-2.05) \\
\end{array}$ & $\begin{array}{c}0.0146^{* * * *} \\
(3.84)\end{array}$ & $\begin{array}{c}0.0913 * * \\
(2.70) \\
\end{array}$ & $\begin{array}{l}-0.0008 \\
(-0.08) \\
\end{array}$ & $\begin{array}{c}0.5888^{* * * *} \\
(12.89) \\
\end{array}$ & $41.12 \%$ & 1.31 & 707 & 310.06 & 0.0000 \\
\hline 2005-2009 & $\begin{array}{c}-0.1227^{*} \\
(-2.06) \\
\end{array}$ & $\begin{array}{c}0.0146^{* *} \\
(2.94)\end{array}$ & $\begin{array}{c}0.1240^{* *} \\
(3.04) \\
\end{array}$ & $\begin{array}{l}0.0046 \\
(0.51)\end{array}$ & $\begin{array}{c}0.4366^{* * * *} \\
(9.52)\end{array}$ & $56.34 \%$ & 0.84 & 708 & 192.46 & 0.0000 \\
\hline $2006-2010$ & $\begin{array}{c}-0.1615^{* *} \\
(-2.67) \\
\end{array}$ & $\begin{array}{l}0.0063 \\
(1.62) \\
\end{array}$ & $\begin{array}{c}0.0709^{*} \\
(2.15) \\
\end{array}$ & $\begin{array}{l}0.0116 \\
(1.43)\end{array}$ & $\begin{array}{c}0.6266 * * * \\
(9.07)\end{array}$ & $37.34 \%$ & 1.48 & 709 & 143.36 & 0.0000 \\
\hline 2007-2011 & $\begin{array}{c}-0.1162 \\
(-1.93)\end{array}$ & $\begin{array}{c}0.0094^{*} \\
(2.49)\end{array}$ & $\begin{array}{l}0.0572 \\
(1.87)\end{array}$ & $\begin{array}{l}0.0139 \\
(1.69)\end{array}$ & $\begin{array}{c}0.6502^{* * * *} \\
(9.04)\end{array}$ & $34.98 \%$ & 1.61 & 709 & 141.42 & 0.0000 \\
\hline 2008-2012 & $\begin{array}{c}-0.1457^{* *} \\
(-2.75)\end{array}$ & $\begin{array}{l}0.0048 \\
(1.66)\end{array}$ & $\begin{array}{l}0.0455 \\
(1.94)\end{array}$ & $\begin{array}{l}0.0132 \\
(1.82)\end{array}$ & $\begin{array}{c}0.8582 * * * \\
(32.10)\end{array}$ & $14.18 \%$ & 4.53 & 568 & $1,215.58$ & 0.0000 \\
\hline Full Sample & $\begin{array}{c}-0.1957 * * * \\
(-3.96) \\
\end{array}$ & $\begin{array}{c}0.0154^{* * *} \\
(3.89) \\
\end{array}$ & $\begin{array}{c}0.0826^{*} \\
(2.47)\end{array}$ & $\begin{array}{l}0.0051 \\
(0.71) \\
\end{array}$ & $\begin{array}{c}0.4734^{* * * *} \\
(18.15)\end{array}$ & $52.66 \%$ & 0.93 & 1,276 & 502.70 & 0.0000 \\
\hline
\end{tabular}

Copyright by author(s); CC-BY

2061

The Clute Institute 


\section{Robustness Test}

The study used two further tests to check for the robustness of the rejection of the market timing theory. The first robustness test involved using the market timing measure suggested by Baker and Wurgler (2002), the $E F W A M B_{t}^{B W}$. Following Bruinshoofd and De Haan (2012), this measure was computed using only long-term debt. Thus regression model 1 was modified to:

$$
L e v_{i, t+1}=\alpha+(1-\lambda) L e v_{i, t}+\lambda\left(\boldsymbol{X}_{i, t} \gamma_{1}\right)+\lambda \gamma_{2} E F W A M B_{t}^{B W}+c_{i, t}+\varepsilon_{i, t+1}
$$

This is regression model 3. To validate the market timing theory, $E F W A M B_{t}^{B W}$ must be significantly correlated to leverage, otherwise the market timing theory is rejected.

The second robustness test was suggested by Bruinshoofd and De Haan (2012) and uses two alternative market timing measures namely the external equity-weighted average market-to-book ratio (EEWAMB) and the long-term debt-weighted average market-to-book ratio (DWAMB), defined as follows:

$$
\begin{aligned}
& E E W A M B_{t}=\frac{1}{\overline{M B}} \sum_{s=1}^{t-1} \frac{e_{s}}{\sum_{r=1}^{t-1} e_{r}} \times M B_{s} \\
& D W A M B_{t}=\frac{1}{\overline{M B}} \sum_{s=1}^{t-1} \frac{l t d_{s}}{\sum_{r=1}^{t-1} l t d_{r}} \times M B_{s}
\end{aligned}
$$

These measures separately test for the market timing hypothesis of both equity and debt issuance decisions. The $D W A M B_{t}$ uses only long-term debt issuance, as this is more likely to represent market timing than short-term debt does. The regression model 1 partial adjustment model is therefore restated as:

$L e v_{i, t+1}=\alpha+(1-\lambda) L e v_{i, t}+\lambda\left(\boldsymbol{X}_{i, t} \gamma_{1}\right)+\lambda \gamma_{2} E E W A M B_{t}+\lambda \gamma_{3} D W A M B_{t}+c_{i, t}+\varepsilon_{i, t+1}$

This is regression model 4. A significant negative correlation between leverage and $E E W A M B$ confirms the validity of the market timing theory, whilst a positive correlation validates the static trade-off theory. A significant positive correlation between $D W A M B$ and leverage validates the market timing theory. The results of both tests are contained in Tables 6 and 7 respectively. 
Regression model 3 results:

$\operatorname{Lev}_{i, t+1}=(1-\lambda) L e v_{i, t}+\lambda\left(\boldsymbol{X}_{i, t} \gamma_{1}\right)+\lambda \gamma_{2} E F W A M B_{t}^{B W}+c_{i, t}+\varepsilon_{i, t+1}$

Where $\lambda$ is the SOA towards the target leverage, $\boldsymbol{X}_{i, t}$ is a vector of firm characteristics that determine the target leverage and the SOA towards the target leverage, $\gamma_{1}$ and $\gamma_{2}$ are coefficient vectors, $c_{i}$ is the time-invariant unobserved variable (firm fixed effect) and $\varepsilon_{i, t+1}$ is an error term. The vector $\boldsymbol{X}_{i, t}$ consists of the variables: profitability, size, tangibility and the un-weighted market-to-book ratio, and these are defined in Table 3. EFWAMB $B_{t}^{B W}$ is the modified Baker and Wurgler (2002:12)market timing measure which is also defined in Table 3. T-statistics are reported in parentheses. The markings $* * * * *$ and $*$ on coefficient estimates denote significant differences from zero at the levels of $1 \%, 5 \%$ and $10 \%$ respectively. The implied half-life is calculated as: half - life $=\log (0.5) / \log (1-\lambda)$. Model specifications are shown under fit statistics.

Table 6. Robustness Test: The Impact of the Modified Baker and Wurgler (2002:12) Market Timing Measure on Capital Structure Regressions

\begin{tabular}{|c|c|c|c|c|c|c|c|c|c|c|c|}
\hline & \multicolumn{5}{|c|}{ Variables } & \multicolumn{3}{|c|}{ Speed of Adjustment } & \multicolumn{3}{|c|}{ Fit Statistics } \\
\hline & Profitability & Size & Tangibility & МТВ & $E F W A M B_{t}^{B W}$ & $\begin{array}{c}\text { Lev_t }+1 \\
\text { Coefficient }\end{array}$ & SOA $(\lambda)$ & $\begin{array}{c}\text { Half-life } \\
\text { (years) }\end{array}$ & Obs & Wald Chi2 & $\begin{array}{c}\text { Prob> } \\
\text { Chi2 }\end{array}$ \\
\hline \multicolumn{12}{|c|}{ Market Leverage (MDR) } \\
\hline 2003-2007 & $\begin{array}{c}-0.2162 * * * \\
(-3.36)\end{array}$ & $\begin{array}{c}0.0039 \\
(1.14)\end{array}$ & $\begin{array}{c}0.0504 \\
(1.55)\end{array}$ & $\begin{array}{c}-0.0055 \\
(-0.57)\end{array}$ & $\begin{array}{c}0.0439 * \\
(2.30)\end{array}$ & $\begin{array}{c}0.6345^{* * *} \\
(9.95)\end{array}$ & $36.55 \%$ & 1.52 & 694 & 221.06 & 0.0000 \\
\hline 2004-2008 & $\begin{array}{c}-0.1730 * * \\
(-2.63)\end{array}$ & $\begin{array}{c}0.0108^{* *} \\
(2.62)\end{array}$ & $\begin{array}{l}0.0707 \\
(1.94)\end{array}$ & $\begin{array}{c}-0.0069 \\
(-0.66)\end{array}$ & $\begin{array}{l}0.0271 \\
(1.56)\end{array}$ & $\begin{array}{c}0.5928 * * * \\
(10.00)\end{array}$ & $40.72 \%$ & 1.33 & 694 & 219.59 & 0.0000 \\
\hline 2005-2009 & $\begin{array}{c}-0.1709^{* *} \\
(-2.68)\end{array}$ & $\begin{array}{c}0.0093 \\
(1.94) \\
\end{array}$ & $\begin{array}{l}0.0684 \\
(1.72)\end{array}$ & $\begin{array}{c}-0.0128 \\
(-1.24)\end{array}$ & $\begin{array}{l}0.0232 \\
(1.46)\end{array}$ & $\begin{array}{c}0.4868 * * * \\
(7.01)\end{array}$ & $51.32 \%$ & 0.96 & 696 & 127.36 & 0.0000 \\
\hline 2006-2010 & $\begin{array}{c}-0.1613^{*} \\
(-2.54) \\
\end{array}$ & $\begin{array}{c}0.0101 * \\
(1.98) \\
\end{array}$ & $\begin{array}{c}0.1045^{* *} \\
(2.59) \\
\end{array}$ & $\begin{array}{c}-0.0108 \\
(-1.15) \\
\end{array}$ & $\begin{array}{l}0.0247 \\
(1.60)\end{array}$ & $\begin{array}{c}0.4243 * * * \\
(6.89)\end{array}$ & $57.57 \%$ & 0.81 & 700 & 125.75 & 0.0000 \\
\hline 2007-2011 & $\begin{array}{c}-0.1257^{*} \\
(-2.26)\end{array}$ & $\begin{array}{l}0.0022 \\
(0.76)\end{array}$ & $\begin{array}{l}0.0576 \\
(2.30)\end{array}$ & $\begin{array}{c}-0.0075 \\
(-1.00)\end{array}$ & $\begin{array}{c}0.0459^{*} \\
(2.20)\end{array}$ & $\begin{array}{c}0.8155^{* * *} \\
(15.03)\end{array}$ & $18.45 \%$ & 3.40 & 703 & 400.73 & 0.0000 \\
\hline 2008-2012 & $\begin{array}{c}-0.1406^{*} \\
(-2.47) \\
\end{array}$ & $\begin{array}{l}0.0027 \\
(0.90)\end{array}$ & $\begin{array}{c}0.0629 * \\
(2.51)\end{array}$ & $\begin{array}{c}-0.0071 \\
(-0.85) \\
\end{array}$ & $\begin{array}{l}0.0340 \\
(1.28)\end{array}$ & $\begin{array}{c}0.7994 * * * \\
(25.67)\end{array}$ & $20.06 \%$ & 3.10 & 564 & $1,009.40$ & 0.0000 \\
\hline Full Sample & $\begin{array}{c}-0.2211^{* * *} \\
(-4.49)\end{array}$ & $\begin{array}{c}0.0075^{*} \\
(2.21) \\
\end{array}$ & $\begin{array}{c}0.0795^{* *} \\
(2.79) \\
\end{array}$ & $\begin{array}{c}-0.0082 \\
(-1.08) \\
\end{array}$ & $\begin{array}{c}0.0395^{*} \\
(2.40)\end{array}$ & $\begin{array}{c}0.5811 * * * \\
(16.11)\end{array}$ & $41.89 \%$ & 1.28 & 1,258 & 490.11 & 0.0000 \\
\hline \multicolumn{12}{|c|}{ Book Leverage ( BDR ) } \\
\hline 2003-2007 & $\begin{array}{c}-0.2264^{* * *} \\
(-3.32)\end{array}$ & $\begin{array}{c}0.0152^{* *} \\
(3.10)\end{array}$ & $\begin{array}{c}0.0937^{*} \\
(2.23) \\
\end{array}$ & $\begin{array}{c}-0.0039 \\
(-0.39) \\
\end{array}$ & $\begin{array}{c}0.0273 \\
(1.49)\end{array}$ & $\begin{array}{c}0.4055^{* * *} \\
(9.72)\end{array}$ & $59.45 \%$ & 0.77 & 705 & 183.73 & 0.0000 \\
\hline 2004-2008 & $\begin{array}{c}-0.1276^{*} \\
(-2.07) \\
\end{array}$ & $\begin{array}{c}0.0145^{* * *} * \\
(3.82)\end{array}$ & $\begin{array}{c}0.0907 * * \\
(2.69)\end{array}$ & $\begin{array}{c}-0.0009 \\
(-0.10) \\
\end{array}$ & $\begin{array}{l}0.0020 \\
(0.12)\end{array}$ & $\begin{array}{c}0.5909^{* * *} \\
(12.89)\end{array}$ & $40.91 \%$ & 1.32 & 704 & 310.29 & 0.0000 \\
\hline 2005-2009 & $\begin{array}{c}-0.1231^{*} \\
(-2.07)\end{array}$ & $\begin{array}{c}0.0144 * * \\
(2.90)\end{array}$ & $\begin{array}{c}0.1240^{* *} \\
(3.03)\end{array}$ & $\begin{array}{c}0.0036 \\
(0.39)\end{array}$ & $\begin{array}{c}0.0074 \\
(0.52)\end{array}$ & $\begin{array}{c}0.4353^{* * *} * \\
(9.38)\end{array}$ & $56.47 \%$ & 0.83 & 705 & 192.20 & 0.0000 \\
\hline 2006-2010 & $\begin{array}{c}-0.1628 * * \\
(-2.70)\end{array}$ & $\begin{array}{l}0.0061 \\
(1.59)\end{array}$ & $\begin{array}{c}0.0691^{*} \\
(2.12)\end{array}$ & $\begin{array}{l}0.0119 \\
(1.45)\end{array}$ & $\begin{array}{c}-0.0039 \\
(-0.24)\end{array}$ & $\begin{array}{c}0.6335^{* * *} * \\
(9.25)\end{array}$ & $36.65 \%$ & 1.52 & 707 & 147.53 & 0.0000 \\
\hline $2007-2011$ & $\begin{array}{c}-0.1144 \\
(-1.90)\end{array}$ & $\begin{array}{c}0.0095^{*} \\
(2.55)\end{array}$ & $\begin{array}{l}0.0569 \\
(1.87)\end{array}$ & $\begin{array}{l}0.0150 \\
(1.81)\end{array}$ & $\begin{array}{c}-0.0170 \\
(-0.84) \\
\end{array}$ & $\begin{array}{c}0.6561 * * * \\
(9.45)\end{array}$ & $34.39 \%$ & 1.64 & 708 & 151.20 & 0.0000 \\
\hline 2008-2012 & $\begin{array}{c}-0.1444^{* *} \\
(-2.73)\end{array}$ & $\begin{array}{l}0.0052 \\
(1.83)\end{array}$ & $\begin{array}{c}0.0465^{*} \\
(1.99)\end{array}$ & $\begin{array}{c}0.0157^{*} \\
(2.12) \\
\end{array}$ & $\begin{array}{c}-0.0396 \\
(-1.69) \\
\end{array}$ & $\begin{array}{c}0.8594 * * * \\
(32.20)\end{array}$ & $14.06 \%$ & 4.57 & 568 & $1,223.19$ & 0.0000 \\
\hline Full Sample & $\begin{array}{c}-0.1964 * * * \\
(-3.97)\end{array}$ & $\begin{array}{c}0.0153^{* * * *} \\
(3.87)\end{array}$ & $\begin{array}{c}0.0826^{*} \\
(2.47)\end{array}$ & $\begin{array}{c}-0.0045 \\
(-0.61)\end{array}$ & $\begin{array}{l}0.0056 \\
(0.36)\end{array}$ & $\begin{array}{c}0.4728^{* * *} \\
(25.86)\end{array}$ & $52.72 \%$ & 0.93 & 1,273 & 502.79 & 0.0000 \\
\hline
\end{tabular}

Copyright by author(s); CC-BY 
Regression model 4 results:

$\operatorname{Lev}_{i, t+1}=\alpha+(1-\lambda) L e v_{i, t}+\lambda\left(\boldsymbol{X}_{i, t} \gamma_{1}\right)+\lambda \gamma_{2} E E W A M B_{t}+\lambda \gamma_{3} D W A M B_{t}+c_{i, t}+\varepsilon_{i, t+1}$

Where $\lambda$ is the SOA towards the target leverage, $\boldsymbol{X}_{i, t}$ is a vector of firm characteristics that determine the target leverage and the SOA towards the target leverage, $\gamma_{1}, \gamma_{2}$ and $\gamma_{3}$ are coefficient vectors, $c_{i}$ is the time-invariant unobserved variable (firm fixed effect) and $\varepsilon_{i, t+1}$ is an error term. The vector $\boldsymbol{X}_{i, t}$ consists of the variables: profitability, size, tangibility and the un-weighted market-to-book ratio, and these are defined in Table 3. EEWAMB $B_{t}$ and $D W A M B_{t}$ are the Bruinshoofd and De Haan (2012) equity and debt timing measures respectively; these are defined in Table 3. T-statistics are reported in parentheses. The markings ***, ** and * on coefficient estimates denote significant differences from zero at the levels of $1 \%, 5 \%$, and $10 \%$ respectively. The implied half-life is calculated as: half - life $=\log (0.5) / \log (1-\lambda)$. Model specifications are shown under fit statistics.

Table 7. Robustness Test: The Impact of Separate Equity and Debt Market Timing Measures on Capital Structure Regressions

\begin{tabular}{|c|c|c|c|c|c|c|c|c|c|c|c|c|}
\hline \multicolumn{7}{|c|}{ Variables } & \multicolumn{3}{|c|}{ Speed of Adjustment } & \multicolumn{3}{|c|}{ Fit Statistics } \\
\hline & Profitibility & Size & Tangibility & МТВ & $E E W A M B_{t}$ & $D W A M B_{t}$ & $\begin{array}{c}\text { Lev_t+1 } t \\
\text { Coefficient }\end{array}$ & $\operatorname{SOA}(\lambda)$ & $\begin{array}{c}\text { Half-life } \\
\text { (years) }\end{array}$ & Obs & Wald Chi2 & Prob $>$ Chi2 \\
\hline \multicolumn{13}{|c|}{ Market Leverage (MDR) } \\
\hline $2003-2007$ & $\begin{array}{c}-0.2058^{* *} \\
(-3.11)\end{array}$ & $\begin{array}{l}0.0037 \\
(1.05)\end{array}$ & $\begin{array}{c}0.0524 \\
(1.53) \\
\end{array}$ & $\begin{array}{c}-0.0071 \\
(-0.73) \\
\end{array}$ & $\begin{array}{c}0.0224 \\
(0.51)\end{array}$ & $\begin{array}{l}0.0414 \\
(1.44) \\
\end{array}$ & $\begin{array}{c}0.6244 * * * \\
(9.70)\end{array}$ & $35.56 \%$ & 1.47 & 672 & 224.87 & 0.0000 \\
\hline 2004-2008 & $\begin{array}{c}-0.1687^{*} \\
(-2.48)\end{array}$ & $\begin{array}{c}0.0121^{* *} \\
(2.75)\end{array}$ & $\begin{array}{c}0.0668 \\
(1.73)\end{array}$ & $\begin{array}{c}-0.0071 \\
(-0.68)\end{array}$ & $\begin{array}{l}0.0075 \\
(0.20)\end{array}$ & $\begin{array}{c}0.0479 * \\
(2.17)\end{array}$ & $\begin{array}{c}0.5760^{* * *} \\
(9.20)\end{array}$ & $42.40 \%$ & 1.26 & 672 & 209.49 & 0.0000 \\
\hline $2005-2009$ & $\begin{array}{c}-0.1811^{* *} \\
(-2.75)\end{array}$ & $\begin{array}{c}0.0100^{*} \\
(1.98)\end{array}$ & $\begin{array}{l}0.0571 \\
(1.37)\end{array}$ & $\begin{array}{c}-0.0141 \\
(-1.35)\end{array}$ & $\begin{array}{l}0.0414 \\
(1.10)\end{array}$ & $\begin{array}{c}0.0535^{*} \\
(2.48)\end{array}$ & $\begin{array}{c}0.4656^{* * *} \\
(6.75)\end{array}$ & $53.44 \%$ & 0.91 & 675 & 126.87 & 0.0000 \\
\hline $2006-2010$ & $\begin{array}{c}-0.1620^{*} \\
(-2.51) \\
\end{array}$ & $\begin{array}{c}0.0110^{*} \\
(2.09)\end{array}$ & $\begin{array}{c}0.0848^{*} \\
(2.02) \\
\end{array}$ & $\begin{array}{c}-0.0116 \\
(-1.22) \\
\end{array}$ & $\begin{array}{c}0.0668^{*} \\
(1.99) \\
\end{array}$ & $\begin{array}{c}0.0476^{*} \\
(2.22) \\
\end{array}$ & $\begin{array}{c}0.4040^{* * *} \\
(6.54)\end{array}$ & $59.60 \%$ & 0.76 & 677 & 119.12 & 0.0000 \\
\hline $2007-2011$ & $\begin{array}{c}-0.1245^{*} \\
(-2.15) \\
\end{array}$ & $\begin{array}{l}0.0027 \\
(0.90) \\
\end{array}$ & $\begin{array}{l}0.0421 \\
(1.58) \\
\end{array}$ & $\begin{array}{c}-0.0065 \\
(-0.85) \\
\end{array}$ & $\begin{array}{c}0.0834^{*} \\
(2.16) \\
\end{array}$ & $\begin{array}{c}0.0603^{*} \\
(2.16) \\
\end{array}$ & $\begin{array}{c}0.7963 * * * \\
(13.69)\end{array}$ & $20.37 \%$ & 3.04 & 681 & 347.32 & 0.0000 \\
\hline $2008-2012$ & $\begin{array}{c}-0.1287^{*} \\
(-2.25) \\
\end{array}$ & $\begin{array}{l}0.0035 \\
(1.16) \\
\end{array}$ & $\begin{array}{c}0.0396 \\
(1.54)\end{array}$ & $\begin{array}{c}-0.0081 \\
(-0.98) \\
\end{array}$ & $\begin{array}{c}0.1073^{*} \\
(2.20) \\
\end{array}$ & $\begin{array}{c}0.0509 \\
(1.59) \\
\end{array}$ & $\begin{array}{c}0.7965^{* * *} \\
(25.27) \\
\end{array}$ & $20.35 \%$ & 3.05 & 545 & 981.38 & 0.0000 \\
\hline Full Sample & $\begin{array}{c}-0.2014 * * * \\
(-4.03)\end{array}$ & $\begin{array}{c}0.0078^{*} \\
(2.27) \\
\end{array}$ & $\begin{array}{c}0.0681^{*} \\
(2.37) \\
\end{array}$ & $\begin{array}{c}-0.0106 \\
(-1.39) \\
\end{array}$ & $\begin{array}{c}0.0560 \\
(1.68)\end{array}$ & $\begin{array}{l}0.0403 \\
(1.85)\end{array}$ & $\begin{array}{c}0.5859 * * * \\
(15.79)\end{array}$ & $41.41 \%$ & 1.30 & 1,217 & 478.80 & 0.0000 \\
\hline \multicolumn{13}{|c|}{ Book Leverage ( BDR ) } \\
\hline 2003-2007 & $\begin{array}{c}-0.2445 * * * \\
(-3.46)\end{array}$ & $\begin{array}{c}0.0165^{* *} \\
(3.03)\end{array}$ & $\begin{array}{c}0.1016^{*} \\
(2.19)\end{array}$ & $\begin{array}{c}-0.0021 \\
(-0.21)\end{array}$ & $\begin{array}{c}-0.0022 \\
(-0.05)\end{array}$ & $\begin{array}{c}0.0153 \\
(0.57)\end{array}$ & $\begin{array}{c}0.3500^{* * *} \\
(8.30)\end{array}$ & $65.00 \%$ & 0.66 & 683 & 149.47 & 0.0000 \\
\hline 2004-2008 & $\begin{array}{c}-0.1487 * \\
(-2.32)\end{array}$ & $\begin{array}{c}0.0150^{* * * *} \\
(3.72)\end{array}$ & $\begin{array}{c}0.0956^{* *} \\
(2.61)\end{array}$ & $\begin{array}{l}0.0012 \\
(0.13)\end{array}$ & $\begin{array}{c}-0.0009 \\
(-0.03)\end{array}$ & $\begin{array}{c}0.0106 \\
(0.50)\end{array}$ & $\begin{array}{c}0.5700^{* * *} \\
(11.03)\end{array}$ & $43.00 \%$ & 1.23 & 682 & 275.58 & 0.0000 \\
\hline 2005-2009 & $\begin{array}{c}-0.1505^{*} \\
(-2.51) \\
\end{array}$ & $\begin{array}{c}0.0141^{* *} \\
(2.81)\end{array}$ & $\begin{array}{c}0.1254^{* *} \\
(3.03)\end{array}$ & $\begin{array}{c}0.0047 \\
(0.52) \\
\end{array}$ & $\begin{array}{l}0.0302 \\
(0.91)\end{array}$ & $\begin{array}{l}0.0202 \\
(1.06)\end{array}$ & $\begin{array}{c}0.4306^{* * *} \\
(9.23)\end{array}$ & $56.94 \%$ & 0.82 & 684 & 197.87 & 0.0000 \\
\hline 2006-2010 & $\begin{array}{c}-0.1714 * * \\
(-2.87)\end{array}$ & $\begin{array}{l}0.0050 \\
(1.35)\end{array}$ & $\begin{array}{l}0.0530 \\
(1.60)\end{array}$ & $\begin{array}{c}0.0124 \\
(1.56) \\
\end{array}$ & $\begin{array}{c}0.0246 \\
(0.69)\end{array}$ & $\begin{array}{c}0.0253 \\
(1.11)\end{array}$ & $\begin{array}{c}0.6664 * * * \\
(8.62)\end{array}$ & $33.36 \%$ & 1.71 & 684 & 152.86 & 0.0000 \\
\hline 2007-2011 & $\begin{array}{c}-0.1026 \\
(-1.80)\end{array}$ & $\begin{array}{c}0.0079 * \\
(2.43)\end{array}$ & $\begin{array}{c}0.0342 \\
(1.22)\end{array}$ & $\begin{array}{c}0.0112 \\
(1.40)\end{array}$ & $\begin{array}{c}0.0298 \\
(0.81)\end{array}$ & $\begin{array}{l}0.0119 \\
(0.44)\end{array}$ & $\begin{array}{c}0.7523^{* * *} \\
(9.45)\end{array}$ & $24.77 \%$ & 2.44 & 686 & 206.15 & 0.0000 \\
\hline 2008-2012 & $\begin{array}{c}-0.1412^{* *} \\
(-2.65)\end{array}$ & $\begin{array}{l}0.0048 \\
(1.65)\end{array}$ & $\begin{array}{c}0.0344 \\
(1.43)\end{array}$ & $\begin{array}{c}0.0122 \\
(1.66)\end{array}$ & $\begin{array}{c}0.0399 \\
(0.87)\end{array}$ & $\begin{array}{l}0.0135 \\
(0.45)\end{array}$ & $\begin{array}{c}0.8514 * * * \\
(29.90)\end{array}$ & $14.86 \%$ & 4.31 & 549 & $1,094.57$ & 0.0000 \\
\hline Full Sample & $\begin{array}{c}-0.2004 * * * \\
(-3.97)\end{array}$ & $\begin{array}{c}0.0161 * * * \\
(3.84)\end{array}$ & $\begin{array}{c}0.0848^{*} \\
(2.34)\end{array}$ & $\begin{array}{c}0.0041 \\
(0.55)\end{array}$ & $\begin{array}{c}0.0120 \\
(0.38)\end{array}$ & $\begin{array}{l}0.0163 \\
(0.80)\end{array}$ & $\begin{array}{c}0.4514 * * * \\
(16.32)\end{array}$ & $54.86 \%$ & 0.87 & 1,232 & 455.43 & 0.0000 \\
\hline \multicolumn{6}{|c|}{ Copyright by author(s); CC-BY } & 2064 & & & & \multicolumn{3}{|c|}{ he Clute Institute } \\
\hline
\end{tabular}




\section{Regression Model 3: Robustness Test Results}

\section{Robustness Test 1}

The results of the test are contained in Table 6. The test results are consistent with the main empirical results. Both the MDR and the BDR decrease with an increase in both profitability and growth rate. Size and tangibility are positively related to the MDR and the BDR. Profitability and size are significant determinants of both the MDR and the BDR. The market timing measure, $E F W A M B_{t}^{B W}$ is positively correlated to both the MDR and the $\mathrm{BDR}$, and these results reject the market timing theory hypothesis. The SOA is within the range of the main empirical tests. The sample SOA is $41.89 \%$ (half-life of 1.28 years) for the MDR and $52.72 \%$ (half-life of 0.93 years) for the BDR. This implies that the $E F W A M B_{t}^{B D}$ and $E F W A M B_{t}^{B W}$ market timing measures do not differ significantly. The findings on the SOA validate the dynamic trade-off theory. The market timing measure has a negligible impact on the correlation of the variables and on the SOA.

\section{Regression Model 4: Robustness Test 2}

The results of the test are contained in Table 7. The correlation results for profitability, size, tangibility and growth rate are similar to those of the main empirical tests. The timing of both equity and debt issuances is positively correlated to both the MDR and the BDR. The results reject the hypothesis of the market timing theory. As with test 1, the SOA results are within the range of the main empirical findings. The SOA is $41.41 \%$ (half-life of 1.30 years) for the MDR and $54.86 \%$ (half-life of 0.87 years) for the BDR. The results of the two tests confirm the robustness of the main empirical findings. The market timing theory is thus rejected. This implies that non-financial firms listed on the JSE do not follow the predictions of the market timing theory in security issuances. Overall, the results support the pecking order theory and the two versions of the trade-off theory, namely the static trade-off theory and the dynamic trade-off theory.

\section{CONCLUSION}

Although the market timing theory offers sound reasons for why managers should time both the equity and debt markets in making security issuance decisions, the results of this study soundly reject the validity of the market timing theory. The results are robust and they generally support the pecking order and dynamic trade-off theories. The positive correlation between leverage and all the market timing measures suggests that South African managers do not time the market in raising capital. Instead, they have target leverage ratios towards which they actively rebalance at relatively higher speeds, and this validates the dynamic trade-off theory. Furthermore, in line with the validity of the pecking order theory, the managers value financial flexibility. The results of the study further confirm the fact that the trade-off and pecking order theories are not mutually exclusive. This finding is consistent with the findings of Moyo et al (2013) and Ramjee and Gwatidzo (2012).

The findings of this study are limited to JSE-listed non-financial firms. The study specifically excluded listed financial services firms and unlisted firms, and therefore the results cannot be generalised to all South African firms. The second limitation to this research is that it only used the random effects Tobit estimator. A study by Moyo et al (2013) found that correlation and SOA parameter estimates also depend on the estimator used to fit the partial adjustment model. Future studies could use other linear dynamic panel data estimators such as the biascorrected least squares dummy variable (LSDV), system generalized methods of moments (GMM), difference GMM and the Anderson-Hsiao instrumental variables to test for the validity of the market timing, dynamic trade-off and pecking order theories. To further improve the understanding of corporate financing behaviour in South Africa, the tests could also be extended to financial services and unlisted non-financial firms. 


\section{AUTHOR INFORMATION}

Vusani Moyo is an Associate Professor at the University of Venda, South Africa. He obtained his PhD (Financial Management Sciences), an MSc (Finance) and MBA (Finance) from the University of Pretoria, University of Leicester School of Management and the University of Manchester Business School respectively. His current research interests are capital structure of African financial and non-financial firms, cash flow sensitivity of cash, investment cash flow sensitivity of cash, cost of capital, firm valuation and dividend policy.

\section{REFERENCES}

Alti, A. (2006). How persistent is the impact of market timing on capital structure? The Journal of Finance, 61(4):1681-1710.

Alti, A. \& Sulaeman.J. (2012). When do high stock returns trigger equity issues? Journal of Financial Economics, 103(1):61-87.

Antoniou, A., Guney, Y. \& Paudyal, K. (2008). The determinants of capital structure: capital market oriented versus bank oriented institutions. Journal of Financial and Quantitative Analysis, 43(1):59-92.

Baker, M. \& Wurgler, J. (2002). Market timing and capital structure. The Journal of Finance, 57(1):1-32.

Barclay, M.J. \& Smith, C.W. (2005). The capital structure puzzle: the evidence revisited. Journal of Applied Corporate Finance, 17(1):8-17.

Barry, C.B., Mann, S.C., Mihov, V.T. \& Rodriguez, M. (2008). Corporate debt issuance and the historical level of interest rates. Financial Management, 37(3):413-430.

Baxamusa, M. (2011). How well do market timing, catering, and classical theories explain corporate decisions? Journal of Financial Research, 34(2):217-239.

Blundell, R. \& Bond, S. (1998). Initial conditions and moment restrictions in dynamic panel data models. Journal of Econometrics, 87(1):115-143.

Booth, L., Aivazian, V., Demirguc-Kunt, A. \& Maksimovic, V. (2001). Capital structures in developing countries. The Journal of Finance, 56(1):87-130.

Bruinshoofd, W.A. \& De Haan, L. (2012). Market timing and corporate capital structure: A transatlantic comparison. Applied Economics, 44(28):3691-3703.

Burch, T.R., Christie, W.G. \& Nanda, V. (2004). Do firms time equity offerings? Evidence from the 1930s and 1940s. Financial Management, 33(1):5-23.

Byoun, S. (2008). How and when do firms adjust their capital structures towards target leverage? The Journal of Finance, 63(6):3069-3096.

Chan, K., Ikenberry, D.L. \& Lee,I. (2007). Do manager time the market? Evidence from open-market share repurchases. Journal of Banking \& Finance, 31(9):2673-2694.

Bougatef, K. \& Chichti, J.E. (2010). Equity market timing and capital structure: Evidence from Tunisia and France. International Journal of Business and Management, 5(10):167-177.

De Angelo, H. \& Masulis, R.W. (1980). Optimal capital structure under corporate and personal taxation. Journal of Financial Economics, 8(1):3-39.

De Bie, T. \& De Haan, L. (2007). Market timing and capital structure: evidence from Dutch firms. De Economist, 155(2):183-206.

De Jong, A. Kabir, R. \& Nguyen T.T. (2008). Capital structure around the world: the role of firm-and countryspecific determinants. Journal of Banking \& Finance, 32(9):1954-1969.

Denis, D.J. (2012). The persistent puzzle of corporate capital structure: Current challenges and new directions. The Financial Review, 47(4):631-643.

Dittmar, A.K. (2000). Why do firms repurchase stock? Journal of Business, 73(3):331-355.

Dittmar, A. \& Thakor, A. (2007). Why do firms issue equity? The Journal of Finance, 62(1):1-54.

Dong, M., Loncarski, I., Ter Horst, J. \& Veld, C. (2012). What drives security issuance decisions: Market timing, pecking order, or both? Financial Management, 41(3):637-663.

Drobetz, W. \& Wanzenried, G. (2006). What determines the speed of adjustment to the target capital structure? Applied Financial Economics, 16(13):941-958.

Elliott, W.B., Koeter-Kant, J. \& Warr, R.S. (2008). Market timing and the debt-equity choice. Journal of Financial Intermediation, 17(2):175-197. 
Elsas, R. \& Florysiak, D. (2011). Heterogeneity in the speed of adjustment toward target leverage. International Review of Finance, 11 (2):181-211.

Elsas, R. \& Florysiak, D. (2013). Dynamic capital structure adjustment and the impact of fractional dependent variables. Working Paper, Institute of Finance and Banking, University of Munich, 1-44. [Online] Available from: $\mathrm{http}: / /$ papers.ssrn.com/sol3/papers.cfm?abstract id=1632362 [Downloaded: 2011-12-10].

Fama, E.F. \& MacBeth, J.D. (1973). Risk, return, and equilibrium: empirical tests. Journal of Political Economy, 81(3):607-636.

Fan, J.P.H., Wei, K.C.J \& Xu, X. (2011). Corporate finance and governance in emerging markets: a selective review and agenda for future research. Journal of Corporate Finance, 17(2):207-214.

Flannery, M. \& Rangan, K. (2006). Partial adjustment toward target capital structures. Journal of Financial Economics, 79(3):469-506.

Frank, M.Z. \& Goyal, V.K. (2004). The effect of market conditions on capital structure adjustment. Finance Research Letters, 1(1):47-55.

Frank, M.Z. \& Goyal, V.K. (2009). Capital structure decisions: which factors are reliably important? Financial Management, 38(1):1-37.

Giambona, E., Mello, A. \& Riddiough, T. (2012). Collateral and the limit of debt capacity: theory and evidence. Working Paper, 1-59. [Online] Available from: http://ssrn.com/abstract=2039253 [Downloaded: 2014-0605].

Graham, J.R. \& Harvey, C.R. (2001). The theory and practice of corporate finance: evidence from the field. Journal of Financial Economics, 60(2-3):187-243.

Gwatidzo, T. \& Ojah, K. (2009). Corporate capital structure: evidence from five African countries. The African Finance Journal, 11(1):1-23.

Henderson, B.J., Jagadeesh, N. \& Weisbach, M.S. (2006). World markets for raising new capital. Journal of Financial Economics, 82(1):63-101.

Hovakimian.A. (2006). Are observed capital structures determined by equity market timing? The Journal of Financial and Quantitative Analysis, 41(1):221-243.

Hovakimian, A., Hovakimian, G. \& Tehranian, H. (2004). Determinants of target capital structure: the case of dual debt and equity issues. Journal of Financial Economics, 71(3):517-540.

Hovakimian, A. \& Li, G. (2011). In search of conclusive evidence: how to test for adjustment to target capital structure. Journal of Corporate Finance, 17(1):33-44.

Hovakimian, A., Opler, T. \& Titman, S. (2001). The debt-equity choice. Journal of Financial and Quantitative Analysis, 36(1):1-24.

Hovakimian, A., Opler, T. \& Titman, S. (2002). The capital structure choice: new evidence for a dynamic trade-off model. Journal of Applied Corporate Finance, 15(1):24-30.

Huang, R. \& Ritter, J.R. (2009). Testing theories of capital structure and estimating the speed of adjustment. Journal of Financial and Quantitative Analysis, 44(2):237-271.

Ikenberry, D., Lakonishok, J. \& Vermaelen, T. (2000). Stock repurchases in Canada: performance and strategic trading. The Journal of Finance, 55(5):2373-2397.

Jensen, M.C. (1986). Agency costs of free cash flow, corporate finance and takeovers. The American Economic Review, 76(2):323-329.

Jenter, D. (2005). Market timing and managerial portfolio decisions. The Journal of Finance, 60(4):1903-1949.

Ju, N., Parrino, R., Poteshman, A.M. \& Weisbach, M.S. (2005). Horses and rabbits? Trade-off theory and optimal capital structure. The Journal of Financial and Quantitative Analysis, 40(2):259-281.

Kayhan, A. \& Titman, S. (2007). Firms' histories and their capital structures. Journal of Financial Economics, $83(1): 1-32$.

Korajczyk, R.A., Lucas, D.J. \& McDonald, R.L. (1992). Equity issues with time-varying asymmetric information. The Journal of Financial and Quantitative Analysis, 27(3):397-417.

Kraus, A. \& Litzenberger, R.H. (1973). A state-preference model of optimal financial leverage. The Journal of Finance, 28(4):911-922.

Leary, M.T. \& Roberts, M.R. (2005). Do firms rebalance their capital structures? The Journal of Finance, 60(6):2575-2619.

Leland, H.E. (1994). Corporate debt value, bond covenants, and optimal capital structure. The Journal of Finance, 49(4):1213-1252. 
Lucas, D.J. \& McDonald, R.L. (1990). Equity issues and stock price dynamics. The Journal of Finance, 45(4):10191043.

Mahajan, A. \&Tartaroglu, S. (2008). Equity market timing and capital structure: International evidence. Journal of Banking \& Finance, 32(5):754-766.

Marsh, P. (1982). The choice between equity and debt: an empirical study. The Journal of Finance, 37(1):121-144.

Modigliani, F. \& Miller, M.H. (1963). Taxes and the cost of capital: a correction. American Economic Review, 53(3):433-443.

Moyo, V., Wolmarans, H. \& Brümmer, L. (2013). Trade-off or pecking order hypothesis? Evidence from South African manufacturing, mining and retail firms, International Business \& Economics Research Journal, 12(8):927-944.

Mukherjee, S. \& Mahakud, J. (2012). Are trade-off and pecking order theories of capital structure mutually exclusive? Evidence from Indian manufacturing firms. Journal of Management Research, 12(1):41-55.

Myers, S.C. (1984). The capital structure puzzle. The Journal of Finance, 39(3):575-592.

Myers, S. (2001). Capital structure. Journal of Economic Perspectives, 15(2):81-102.

Myers, S.C. \& Majluf, N.S. (1984). Corporate financing and investment decisions when firms have information that investors do not. Journal of Financial Economics, 13(2):187-221.

Oztekin, O. \& Flannery, M.J. (2012). Institutional determinants of capital structure adjustment speeds. Journal of Financial Economics, 103(1):88-112.

Peyer, U. \& Vermaelen, T. (2009). The nature and persistence of buyback anomalies. The Review of Financial Studies, 22(4):1693-1745.

Rajan, R.G. \& Zingales, L. (1995). What do we know about capital structure? Some evidence from international data. The Journal of Finance, 50(5):1421-1460.

Ramjee, A. \& Gwatidzo, T. (2012). Dynamics in capital structure determinants in South Africa. Meditari Accountancy Research, 20(1):52-67.

Shyam-Sunder, L. \& Myers, S.C. (1999). Testing static trade-off against pecking order models of capital structure. Journal of Financial Economics, 51(2):219-244.

Singh, A. (1999). Should Africa Promote Stock Market Capitalism? Journal of International Development, 11(3) 343-365.

Smith Jnr, C.W. (1986). Investment banking and the capital acquisition process. Journal of Financial Economics, 15(1-2):3-29.

Spiess, K.D. \& Affleck-Graves, J. (1999). The long-run performance of stock returns following debt offerings. Journal of Financial Economics, 54(1):45-73.

Talberg, M., Winge, C., Frydenberg, S. \& Westgaard, S. (2008). Capital structure across industries. International Journal of the Economics of Business, 15(2):181-200.

Tong, G. \& Green, C.J. (2005). Pecking order or trade-off hypothesis? Evidence on the capital structure of Chinese companies. Journal of Applied Economics, 37(19):2179-2189.

Walker, M.D. \& Yost, K. (2008). Seasoned equity offerings: What firms say, do, and how the market reacts. Journal of Corporate Finance, 14(4):376-386.

Welch I. (2004). Capital structure and stock returns. The Journal of Political Economy, 112(1):106-132.

$\mathrm{Xu}, \mathrm{Z}$. (2009). The impact of market timing on Canadian and US firms' capital structure. Working Paper, 2009-1, 141. 